\title{
Globalization and Protection of Employment
}

Justina A.V. Fischer and Frank Somogyi

\begin{abstract}
Unionists and politicians frequently claim that globalization lowers employment protection of workers. This paper tests this hypothesis in a panel of 28 OECD countries from 1985 to 2003 , differentiating between three dimensions of globalization and two labor market segments. While overall globalization is shown to loosen protection of the regularly employed, it increases regulation in the segment of limited-term contracts. We find economic and political globalization to drive deregulation for the regularly employed, while political and social integration appear responsible for the better protection of workers in atypical employment, outweighing the negative effect of economic integration. We offer political economy arguments as explanations for these differential effects on labor market legislation.
\end{abstract}

Key words: Globalization; International trade; Employment protection; Labor standards

JEL codes: F15, F16, J63, J68, C33

This paper is based on a previous version from 2009 (MPRA Paper 17535). Research for this paper was funded by the Swiss National Science Foundation under a grant to the National Centre of Competence in Research on Trade Regulation and the European Commission (COFUND fellowship), based at the World Trade Institute of the University of Bern, Switzerland. NCCR TRADE WORKING PAPERS are preliminary documents posted on the NCCR Trade Regulation website (<www.nccr-trade.org $>$ ) and widely circulated to stimulate discussion and critical comment. These papers have not been formally edited. Citations should refer to a "NCCR Trade Working Paper", with appropriate reference made to the author (s).

\section{FNSWF}

FONDS NATIONAL SUISS SCHWEIZERISCHER NATIONALFONDS FONDO NAZIONALE SVIZZERO SWISS NATIONAL SCIENCE FOUNDATION 


\title{
Globalization and Protection of Employment ${ }^{\text {ts }}$
}

\author{
Justina A.V. Fischer ${ }^{\mathrm{a}}$, Frank Somogyi $\mathrm{i}^{\mathrm{b}, 1}$ \\ ${ }^{a}$ University of Bern, World Trade Institute, Hallerstrasse 6, 3012 Bern, Switzerland. \\ ${ }^{b}$ Deutsche Bundesbank, Economics Department, Wilhelm-Epstein-Strasse 14, 60431 Frankfurt am Main, Germany.
}

\begin{abstract}
Unionists and politicians frequently claim that globalization lowers employment protection of workers. This paper tests this hypothesis in a panel of 28 OECD countries from 1985 to 2003, differentiating between three dimensions of globalization and two labor market segments. While overall globalization is shown to loosen protection of the regularly employed, it increases regulation in the segment of limited-term contracts. We find economic and political globalization to drive deregulation for the regularly employed, while political and social integration appear responsible for the better protection of workers in atypical employment, outweighing the negative effect of economic integration. We offer political economy arguments as explanations for these differential effects on labor market legislation.
\end{abstract}

Keywords:

Globalization, International trade, Employment protection, Labor standards

\section{Introduction}

The question of a harmonization of labor standards is on the agenda of nearly all intergovernmental meetings on international trade, be it in the framework of the European Union (EU), the North American Free Trade Agreement (NAFTA), or the World Trade Organization (WTO). Such

\footnotetext{
攻Acknowledgment: We thank Christian Bjørnskov, Gernot Doppelhofer, Axel Dreher, Martin Gassebner, Noel Gaston, Christian Keuschnigg, Douglas Nelson, Lars Siemers, and the participants of the RWI research seminar (Essen), the 3rd Macroeconomic Research Meeting (Bonn), the Annual Meeting of the European Public Choice Society (Athens), the Annual Meeting of the Swiss Society of Economics and Statistics (Geneva), and the Annual Congress of the European Economic Association (Oslo) for helpful comments. We thank Andrea Bassanini (OECD) for providing us with panel data on employment protection legislation. We also thank Nadine Fischer (ILO) for providing us with information on international ILO conventions on labor standards. Justina Fischer acknowledges financial support from the EU Marie Curie fellowship scheme (RTN ENABLE) during her stay at the Stockholm School of Economics (Sweden). Research for this paper was funded by the Swiss National Science Foundation under a grant to the National Centre of Competence in Research on Trade Regulation and the European Commission (COFUND fellowship), based at the World Trade Institute of the University of Bern, Switzerland.

Email addresses: mail@justinaavfischer.de (Justina A.V. Fischer), econ@franksomogyi.de (Frank Somogyi)

${ }^{1}$ This paper represents the authors' personal opinions and does not necessarily reflect the views of Deutsche Bundesbank or its staff.
} 
labor standards comprise workers' right to form unions, fix maximum number of working hours and protect against unjustified and mass dismissals - from a producers' point of view thereby imposing additional production costs and threatening the international competitiveness of their firms. Consequently, international competition among producers in countries with heterogeneous labor standards may trigger a race-to-the-bottom (Sinn, 2001; OECD, 2000; ILO, 2009). To prevent such development, some international organizations, for example the WTO and the International Labour Organization (ILO), try to set minimum labor standards, but often do not have the necessary legal means to enforce them (see Krueger, 1996, on the missing enforcement of compulsory schooling laws to prevent child labor). As described in ILO (2009), the means of international enforcement are weak as they include only instruments of 'social dialogues' and 'technical assistance'. ${ }^{2}$ In response, domestic politicians mainly from the political left typically demand a legally binding harmonization of labor standards above the minimum level, or argue even against further expansion of free trade.

This paper tests the claim that globalization leads to such a race-to-the-bottom process that weakens workers' employment protection. Using a panel on measures of globalization and employment protection of 28 member countries of the Organisation for Economic Co-operation and Development (OECD) from 1985 to 2003, we find a substantial influence of globalization on employment protection. A novelty is that this influence is found to differ both across the dimensions of globalization (economic, political, and social) as well as across the different labor market sectors (short-term contract and regular-contract workers). While the economic and political dimensions of globalization are shown to loosen protection of the regularly employed, we find that political and social globalization tighten the laws regulating the possibility of offering/extending limitedor short-term contracts, outweighing the opposite effect of economic globalization. We argue that these differential effects by dimension of globalization and labor market sector are well in line with recent political economy models of international trade, which have three characteristics: lobbying of agents (workers, producers), credibility of politicians necessary to fulfill their transmission channel functions with respect to the agents' opposing preferences, and the relative economic importance of the two labor market sectors.

The remainder of the paper is organized as follows: the next two sections describe previous mostly empirical literature, illustrates more thoroughly the research gap to be filled, and derives testable hypotheses that guide our empirical analysis. Section 4 describes the data on globalization, employment protection and the controlling variables that form part of the empirical model, which

\footnotetext{
${ }^{2}$ The ILO Declaration on Fundamental Principles and Rights at Work, adopted in 1998 and laid down in several separate conventions (no. 29, 87, 98, 105, 111, 138), covers only so-called core labor standards, in particular " 1 ) freedom from forced labor in the form of compulsory labor and slavery, (2) the abolition of exploitative forms of child labor that put the safety and health of children at significant risk, (3) equal opportunity in employment, and (4) fundamental union rights like freedom of association and collective bargaining" (Busse, 2004, p.212). Thus, certain aspects of protection of employment are not covered. The ILO labor standards are summarized and introduced in ILO (2009).
} 
is introduced in Section 4. Section 5 presents the empirical results for the direct effects of economic, political and social globalization on workers' employment conditions, while Section 6 investigates how political conditions may amplify the pressure exerted by globalization. The findings in this paper are finally discussed and concluded in Section 7.

\section{Previous Literature and Contribution of this Paper}

\section{Literature Review}

Most theoretical models of international trade such as the ones by Bhagwati and Srinivasan (1995) and Stern (2003) predict that globalization lowers labor standards due to a race-to-thebottom in regulatory competition along the lines of the seminal Tiebout (1956) model. ${ }^{3}$ As already argued in the review by Brown (2000), free trade prevents passing the additional production costs of complying with certain labor standards on to the consumer, who has the possibility to substitute with cheaper imported goods. Therefore, in open economies these additional production costs have to be borne by the firms and their workers alone. The race to the bottom of labor standards is then the outcome of a prisoners' dilemma game, in which the firm/country that deviates first reaps excessive profits/welfare gains from trade. However, trade theorists emphasize that such a race to the bottom does not occur among small open economies - labor standards are then not able to spill-over across borders - but well in the case of large countries or when small countries have formed large trading blocks that strategically interact. In the case of the economically advanced OECD countries, the latter arguments apply.

In contrast to the theoretical models that predict a negative relation between globalization and labor standards, existing empirical evidence is rather scarce and provides mixed results. ${ }^{4}$ As argued below, most empirical models fail to take into account the multifacetedness of globalization, focusing on foreign trade ('openness') and foreign direct investment (FDI) only. Moreover, while some research on labor market outcomes exists, the impact of globalization on employment protection has been entirely neglected so far.

Most of the early empirical studies employ only flows of FDI as measure of economic globalization and focus only on core labor standards set by the ILO (see footnote 2), but not on general employment protection. Moreover, in this strand of the literature the research question is rather on how costs of labor and social stability affect location decisions of investors, not on how globalization affects the level of labor standards in a country (for an example, see Kucera (2002), and literature cited therein).

\footnotetext{
${ }^{3}$ Theoretical arguments may well go into the opposite direction, predicting the impact of labor standards on trade volume, see also Krueger (1996).

${ }^{4}$ Early empirical analyses on the effect of international trade on relative wages (skilled vs. unskilled) in the USA, wage inequality worldwide, wage stability for production workers, trade and freedom-of-association-rights, trade and rights to non-discrimination are described in Brown (2000).
} 
One of the first contributions to empirically relate trade openness, replacing FDI of the previous analyses, with some specific core labor standards appear to be Shelburne (2001) and Cigno et al. (2002): both papers find independently from each other that trade openness reduces the prevalence of child labor - abolition of child exploitation is one of the core ILO labor conventions.

Busse (2004) uses this research as a starting point and extends it to incorporate also the remaining core labor standards covered by the ILO conventions. He finds in a fixed effects panel analysis of 71 developing countries from 1970 to 2000 that more openness to trade appears to lead to increased gender discrimination in the labor market, growing prevalence of child labor, and less unions rights (freedom of association). Providing the rationale for the deterioration of certain labor standards as national economies become more globalized, Busse and Spielmann (2006) show in a panel fixed effects analysis of a world sample (1975-2000) that gender inequality in wages creates a comparative advantage in the production of labor-intensive commodities. Already ten years earlier, Rodrik (1996) identified long working hours and child labor (controlling for human capital) as determinants of having a comparative advantage in the production of labor-intensive goods. While the empirical analysis by Busse (2004) is an important contribution to the literature on the impact of trade on core labor standards, it does not cover the effects on general employment protection.

In two recent studies, Walter (2010a,b) takes the analysis to the micro level and analyzes the impact of globalization on voters' demand for unemployment insurance as compensation for losses from globalization, distinguishing between low-skilled and high skilled workers. She finds that low-skilled workers perceive their risk of becoming unemployed due to globalization higher than high-skilled workers, and, consequently, demand more generous unemployment insurance than highskilled workers. ${ }^{5}$ However, the author focuses on voters' risk perceptions and resulting demands rather than on policy outcomes, which is the focus of our paper.

Turning to the question of union rights which comes closest to measuring general 'employment protection' of adult workers against e.g. mass dismissals and exploitative work contracts, Dreher and Gaston (2005) find in a cross-section time-series of 17 OECD countries from 1980 to 1999 (with country fixed effects) that globalization adversely affects density and attractiveness of unions - as a consequence of, as they argue, their lower (relative) bargaining power. Testing several dimensions of globalization, one of the few empirical contributions making such a distinction, they find that this development is driven by the social dimension of globalization, which includes worldwide communication, exchange of ideas, and convergence of local cultures. In contrast, the economic and political dimensions do not appear to exert any impact. This is a noteworthy result given that most arguments that link globalization with deunionization are rather economic or political (see e.g. Wallerstein and Western, 2000). In this paper, we will equally distinguish between three dimensions

\footnotetext{
${ }^{5}$ Protte (2011) studies the source of these labor market risk perceptions, namely coverage in newspapers of different political leaning and hence readers of different skill levels and types of jobs.
} 
of globalization, using an updated version of the index used in Dreher and Gaston (2005).

In contrast, contradictory findings to the analysis of Dreher and Gaston (2005) are reported in the empirical study by Golden (2000): in a cross-section of 15 OECD countries for the 1980s (1980-1990) her empirical model reveals a convergence of union strength towards a certain mean, but a divergence in union density. In her study, this union development appears rather unaffected by growing economic integration (measured by trade openness and the absence of restrictions of capital mobility).

\section{Contribution of this Paper}

Our paper is the first to test a direct linkage between the phenomenon 'globalization' and the economic outcome 'employment protection' through laws and administrative regulations: Instead, preceding studies focus largely on aspects of union strength in place of employment protection with union strength assumingly approximating wage levels, wage inequality, and job security (e.g. Blau and Kahn, 1996; Fortin and Lemieux, 1997) as labor market outcomes of globalization; in other words, these studies merely assume a positive link between unionization and employment protection, but fail to empirically show that this link actually exists. In addition, these studies also do not account for the multifacetedness of globalization, focusing on either trade or FDI, ignoring additional economic channels of globalization and their interplays. Indeed, globalization takes place not only in the economic sphere, but also in the social and political spheres. Furthermore, the literature either largely disregards worker heterogeneity or focuses only on differential effects, if at all, on low-skilled and high-skilled workers, and ignore effects on different segments of the labor market. Finally, from a methodological viewpoint, most of these studies neglect the problem of potential endogeneity of international trade, as the study by e.g. Dewit et al. (2009) suggests. ${ }^{6}$

Taken altogether, an issue that has not yet been in the focus of economic analysis is the question to what extent economic, social and political integration into the world impacts legislation that aims at protecting average workers' employment. To fill this gap, this paper is the first a) to empirically test whether and how globalization affects workers' employment protection and b) to provide arguments for these possible linkages. While the violations of core labor standards employed in the previous literature (e.g. child labor) rather address differences between developed and developing countries, we use a measure of employment protection that varies even across economically and institutionally well advanced countries: employment protection of workers measures e.g. the difficulty of (unfairly) dismissing them, their rights for compensation payments, and their exploitation through 'flexible contract' arrangements. To take account of the economic phenomenon of a growing importance of temporary work contracts in the European economies, we look at two

\footnotetext{
${ }^{6}$ Their empirical analysis for OECD countries with the same index of employment protection used in this study suggests that relatively stricter protection of workers' rights deters foreign direct investment, and keeps domestic firms anchored in their home countries.
} 
distinct labor market sectors: that with regular (mostly permanent) work contracts, but equally the sector of short-term contracts and temporary work agency employment.

By using the sub-indices of the KOF Index of Globalization ${ }^{7}$, we take account of the multifacetedness of economic integration that goes beyond simple trade openness and foreign direct investment flows; in addition, using this index allows us to study whether the effects of globalization differ across its various dimensions, namely its economic, social and political dimensions. A battery of robustness tests completes the empirical analysis.

\section{Theoretical Framework and Hypotheses}

\section{Economic Globalization}

As argued above, strict employment protection legislation comes at a cost to domestic firms, possibly leading to their disadvantage in international competition. Hence, producers will demand a reduction of employment protection the stronger, the more intense international economic integration and the resulting inflow of foreign products into the domestic market is (see Fischer, 2012). In contrast, dependently employed workers, which form the majority of the workforce in developed countries, can be assumed to have an interest in staying employed in the first place, whether they hold regular or atypical contracts or not. Thus, all workers likewise expect to profit from a strict employment protection, which they demand from politicians. Consequently, if workers' jobs are put under competitive pressure due to economic globalization, we suspect that workers favor policies that increase the protection of their current jobs, at least in the short run. It is debatable whether workers would be in favor of market deregulation policies that ensure the international competitiveness and the creation of new jobs in the long run, but might jeopardize their present employment. Assuming bounded rationality and hyperbolic discounting, we rather expect workers to prefer protection of the present job over creation of new jobs in the far-away future. However, we cannot completely reject the possibility that laborers with regular contracts may favor the lowering of their job protection if this makes regular work contracts relatively more likely to be chosen by employers than atypical, temporary work contracts. To satisfy the demand for making regular employment more attractive than the atypical one, labor protection in the atypical sector should be increased relative to protection in the regular sector. ${ }^{8}$ On the other hand, laborers may demand higher job protection in exchange for their consent to politicians' decision to increase their country's openness. In a public choice view where politicians respond to the aggregated preferences of the population, with the electorate being diversely composed of workers with regular contracts, laborers with atypical contracts, and firm owners, the net effects of the combined demands by these population groups

\footnotetext{
${ }^{7}$ See Dreher (2006).

${ }^{8}$ The only group univocally being in favor of lowering employment protection in both segments would be the unemployed worker, hoping for faster re-employment when labor market institutions are less rigid.
} 
for employment protection is ambiguous a priori and needs to be determined empirically.

The effects of globalization on the degree of employment protection in the labor market can be more convincingly derived from political economy which assumes that it is the relative bargaining or lobbying power of agents which determines policy outcomes. Given the stronger influence of producers on politicians compared to workers (as there are fewer of them and thus more easily coordinated, and as they have firm reallocation as credible exit option, while labor is immobile), we predict that employment protection in the labor market will, in general, decline. However, the political-economic theory of 'linkage politics', which constitutes some form of issue-bundling resulting in log-rolling, predicts that economic globalization exerts a protectionist impact on one labor market segment, but a deregulative one on the other. The phenomenon of 'linkage politics' was first described in the literature on international negotiations between two countries with diverging interests. Stein (1980) argues that consent to a specific reform that benefits one country can be reached by linking the decision to reciprocal consent on a second reform that benefits the other country. Mayer and Riezman (1987) take a more formal approach and find that such 'policy mixture' (two interlinked reforms) constitutes an equilibrium outcome of a bargaining game between two players, which makes both players better off compared to a situation without an agreement. Application of the 'linkage theory' to the question of globalization effects for employment protection rests on the general political economy assumption of conflicting interests between between two groups: unions, which represent employed workers and prefer stricter employment regulation, and producers, who prefer the opposite. ${ }^{9}$

In application of the theory of 'linkage politics' to our research question, we argue that domestic employees and unions might trade off the detrimental effects of globalization in the regular contract segment with stronger protection in the other, atypical contract segment. Given that the major industrial branches are still in the traditional labor market segment with regular contracts, making it economically more important than the segment with atypical work contracts, employers lobbying for deregulation may be willing to trade more employment protection in the less important segment for less protection in the atypical segment. The statistical facts show that in the EU-15 the share of temporary employment in total dependent employment has risen from 4 percent in 1983 to 15 percent in 2007 (Franco and Winqvist, 2002), so that temporary employment segment is still relatively dominated by the regular employment segment. ${ }^{10}$ Thus, it may well be that producerinfluenced politicians buy support of the worker- and union-dominated electorate for labor market deregulation in the (traditional and economically more important) regular labor market segment by

\footnotetext{
${ }^{9}$ Again, the unemployed workers prefer less employment protection in either labor market segment. According to common economic theory, unions are assumed to maximize the utility of their (employed) members only.

${ }^{10}$ Recent numbers for Germany (2008) indicate that the share of regularly employed (permanent contracts with at least 20 working hours per weak) has declined since 1998 from 72.6 percent to 66 percent, while the share with 'atypical' contracts has increased from 16.2 per cent to 22.2 per cent. The same study reveals that the atypically employed earns only about $2 / 3$ of the wage of a regularly employed (see Statistisches Bundesamt, 2009).
} 
granting stronger employment protection in the less important temporary employment segment. ${ }^{11}$

Increasing labor protection in the atypical sector more relative to protection in the regular sector is facilitated by the fact that regulation in the relatively new atypical employment sector is initially quite low, i.e. politicians deliberately set incentives for employers that are overall welfare-improving: politicians might relatively increase regulation in the temporary-contract sector with the intention to make employers not substitute regular employment with short-term contract/TWA positions. This argument rests on the stylized fact that, even though employment protection for the regularly employed has declined over the last years, their job security still remains substantially higher than that for those in 'atypical' employment. Given this latter sector's minor economic importance, such policy of relatively increasing employment protection in the atypical labor market segment while contemporaneously decreasing overall employment protection still leads to an increase in overall labor market flexibility. We have good reasons to assume that both producers' and unionists' lobbying pressure on politicians may be the stronger, the fiercer international competition and economic globalization is.

Hence, according to the political economy theory of 'linkage politics' and relative lobbying power, we expect economic globalization to decrease employment protection in both labor market segments, also causing a relative increase in protection in the temporary contract labor market segment compared to protection in the regular contract segment. ${ }^{12}$

\section{Social Globalization}

The lobbying pressure exerted by unions or workers might rise with exposure of a wider public to the forces of globalization - reflected in the social dimension of globalization. People may mainly experience or become aware of globalization by own cross-national travel and information exchange through mass media and the internet; notably, without this international communication infrastructure, the existence and success of non-governmental organizations such as attac, Greenpeace or Amnesty International would be unthinkable. Hence, social globalization might lay the grounds for an international coordination of workers' demands and a more forceful formulation, based on a larger support, of their demands for an increase in labor protection. Analogously, producers' lobbying efforts may equally benefit from social globalization as it allows them to exchange information worldwide on regulations and wages in competing countries. Social globalization also enhances the dissemination of lobbying expertise and allows to build informal networks spanning across countries that may be used to increase pressure on politicians to deregulate. Taken altogether, through the

\footnotetext{
${ }^{11}$ Similarly, we may argue that producer-influenced politicians buy support form the worker-dominated electorate for further opening up of domestic markets by increasing employment protection in the economically less important labor market segment.

${ }^{12}$ Note: this does not exclude a decrease in both sectors, if the decrease is larger in the regular sector than in the atypical sector.
} 
international interconnectedness of agents and the resulting flow of information across countries, social globalization may reinforce the demands and lobbying power of both workers and employers likewise. A priori, no prediction with respect to the overall impact of social globalization on employment protection can be made.

\section{Political Globalization}

A similar argumentation applies to globalization in the political dimension through countries' memberships in international and supranational organizations. Both unions' and producers' coordination efforts are potentially supported by such memberships. From the unions' perspective, enhanced international policy coordination makes it easier to sustain stricter labor protection despite growing international competition, as the cost of protection, if applied to all producers around the world equally, does not bias their international competitiveness and, thus, does not affect their relative profits. As in a prisoners' dilemma game, regulation and enforcement through international treaties aid sustain the cooperative equilibrium with strong employment protection, which is to the benefit of the populations in the participating countries (Fischer, 2012; Petersen, 2009). Thus, political globalization might even increase the protection of workers against dismissals and atypical employment conditions, if countries with stricter regulations manage to impose an employment protection policy on other countries by means of their memberships in international organizations, which are a key aspect of political globalization. Examples for such efforts to internationally coordinate on stricter labor market standards include agreements on core labor standards such as the aforementioned ILO conventions and several EU standards concerning ethics in industrial production.

On the other hand, producers, in search for new markets, may internationally coordinate on promoting international trade and tearing down legal and technical obstacles to exporting and importing goods and services. Again, in a prisoners' dilemma game mutually granting access to each other's domestic market represents the cooperative equilibrium, with both players (countries) profiting, while a unilateral (bilateral) imposition of trade-preventing tariffs would leave the other (both) player(s) with a substantial welfare loss (Sinn, 2001). Thus, political globalization may be instrumentalized by producers to increase openness and to access new markets, thus raising international competition and the competitive pressure exerted on domestic labor markets. Examples for such efforts to coordinate on liberalization in international trade include the signing of treaties that established the European Economic Area and the WTO. ${ }^{13}$

Taken altogether, on the one hand, membership in international organizations may well prevent a race of labor standards to the bottom, but, on the other, may also increase the pressure of

\footnotetext{
${ }^{13}$ The notion 'international trade' in this paragraph also captures international capital flows to which very similar arguments can be applied. In such case, stricter employment protection would decrease the return on investment, making investment objects less attractive for foreign and domestic investors.
} 
international competition to deregulate domestic labor markets. Overall, the predicted effects of political globalization on employment protection remain ambiguous.

\section{Overall Globalization}

In addition to the sub-indices for economic, political and social globalization, we also employ a compound measure of globalization combining these three sub-indices. Given the a priori indeterminate effects of social and political globalization on employment protection, we suspect that the direction of the impact of overall globalization is driven by economic globalization, increasing the probability that we will find overall globalization to decrease employment protection.

In a second step of our analysis, we investigate whether the forces of globalization interact with the political condition of a country. In particular, we test whether the influence of a country's degree of international integration varies depending on the political leaning of the governing party.

\section{Data and Empirical Strategy}

\subsection{Employment Protection Legislation}

For our analysis, we use the index of Employment Protection Legislation (EPL), Version 1, provided by OECD (2004) for 28 OECD countries, from 1985 to $2003 .{ }^{14}$ The EPL is based on government information and measures, in general, the protection of workers against specific forms of economic and financial exploitation through their employers. ${ }^{15}$

For regularly employed workers, the relevant EPL index (' $E P L_{r e g}$ ') measures the overall strictness of protection with respect to four areas: The difficulty of individual dismissals, notice and severance pay for no-fault individual dismissals, the overall strictness of protection against dismissals, and regular procedural inconveniences. Thus, this measure takes into account the possible reasons for an individual lay-off, the regulation of advance notice and severance pay, trial periods, conditions under which lay-offs are unjustified, and compensation payment in case of such unjustified dismissals.

In contrast, for workers holding fixed-term work contracts or workers who are employed by temporary work agencies (so-called atypical work contracts), EPL ('EPL $L_{t e m p}$ ') captures the overall strength of restrictions on establishing and maintaining such temporary employment. OECD names

\footnotetext{
${ }^{14}$ The excluded countries are Iceland and Luxembourg with no observations of EPL. The included countries are: Australia, Austria, Belgium, Canada, Czech Republic, Denmark, Finland, France, Germany, Greece, Hungary, Iceland, Ireland, Italy, Japan, South Korea, Luxembourg, Mexico, Netherlands, New Zealand, Norway, Poland, Portugal, Slovak Republic, Spain, Sweden, Switzerland, Turkey, United Kingdom, and the United States of America.

${ }^{15}$ This index excludes aspects of mass dismissals that are taken into account in a more recent version of the EPL index ("Version 2"), which, however, covers a much smaller time span. The first time point of measurement of EPL version 2 is 1998, that of version 1 the year 1985. Notably, as stated in OECD (2004) p.102, the regulation of mass dismissals forms only an additional protection against a rather rare form of lay-off, and in many countries regulations of individual and mass dismissals are fairly identical.
} 
the three areas covered by this EPL index 'fixed-term contracts', 'overall strictness of regulation', and 'temporary work agencies'. These areas include the regulation of the number of possible renewals of fixed-term contracts, the maximum accumulated contract duration (in months), whether fixed-term contracts are generally permitted or restricted to certain industry sectors only, or restricted to certain types of work (e.g. to temporarily replacing a long-term sick worker or a worker on parental leave).

Each EPL index $\left(E P L_{r e g}, E P L_{t e m p}\right)$ ranges from 0 to 6 with continuous intervals, and higher values indicate a stronger employment protection of workers. In general, each EPL index is calculated as an average of points awarded to its specific sub-dimensions in a four-step aggregation procedure (see OECD, 2004, chapter 2). Due to the four-step construction procedure of the index, small changes in the overall index may reflect considerable institutional changes: For example, a change from the oral notification of dismissal to a procedure where a written statement giving reasons must be provided and a work council must be notified increases the EPL index of regular employment by just 0.33 points (see also OECD, 2004, p. 103 and p. 106). Similarly, a move from restricting the number of (consecutive) short-term contracts renewals to having no restrictions decreases the EPL for temporary employment by only 0.125 points. Table 8 of Section 8 provides descriptive statistics of the indices of employment protection in OECD countries.

An overview of the legal and institutional changes in OECD countries with respect to employment protection from 1985 on is reported in Table 7 in section 8. Table 7 also illustrates in what directions these institutional changes influenced the two EPL indices of regular and temporary employment. The general impression is that, on average, since 1985 the EPL index has been falling, for either type of employment. However, in some countries specific labor market reforms had a neutral effect on the index (e.g. Belgium, Germany, Ireland, Japan, Norway, Sweden), while, contrary to the general impression, a few reforms even improved on workers' employment protection (Australia, France, Great Britain, New Zealand). Notably, the effects of these labor market reforms are not even heterogeneous across countries or time, but also within a country across types of employment. For example, Finland and Portugal appear to have liberalized the regular employment sector, while the employment protection index for temporary employment remained unaffected. Similarly, in Korea the reduction in protection in the regular sector was significantly larger than in the temporary sector. The exact opposite observation is made for Germany, Italy and Japan, in which only the protection of the temporarily employed was lowered. Figures 1 and 2 show the development of employment protection in both sectors for a selection of countries. Figure 1 displays the development of employment protection in the regular sector during the time span studied. There is substantial variation between the countries. Within the time series, we see that employment protection has stayed constant over time in some countries (Japan, USA), regardless of the initial level of regulation in these countries, while others have seen substantial decreases in protection (Finland, Korea, Spain), and a few countries have even experienced small increases in employment protection 
(Australia, Germany, France). Furthermore, there seems to be a convergence to a common level of labor protection for the European and Asian countries, decreasing average employment protection in the regular sector.

Figure 1: Employment protection, regular employment, selected countries, 1985-2003

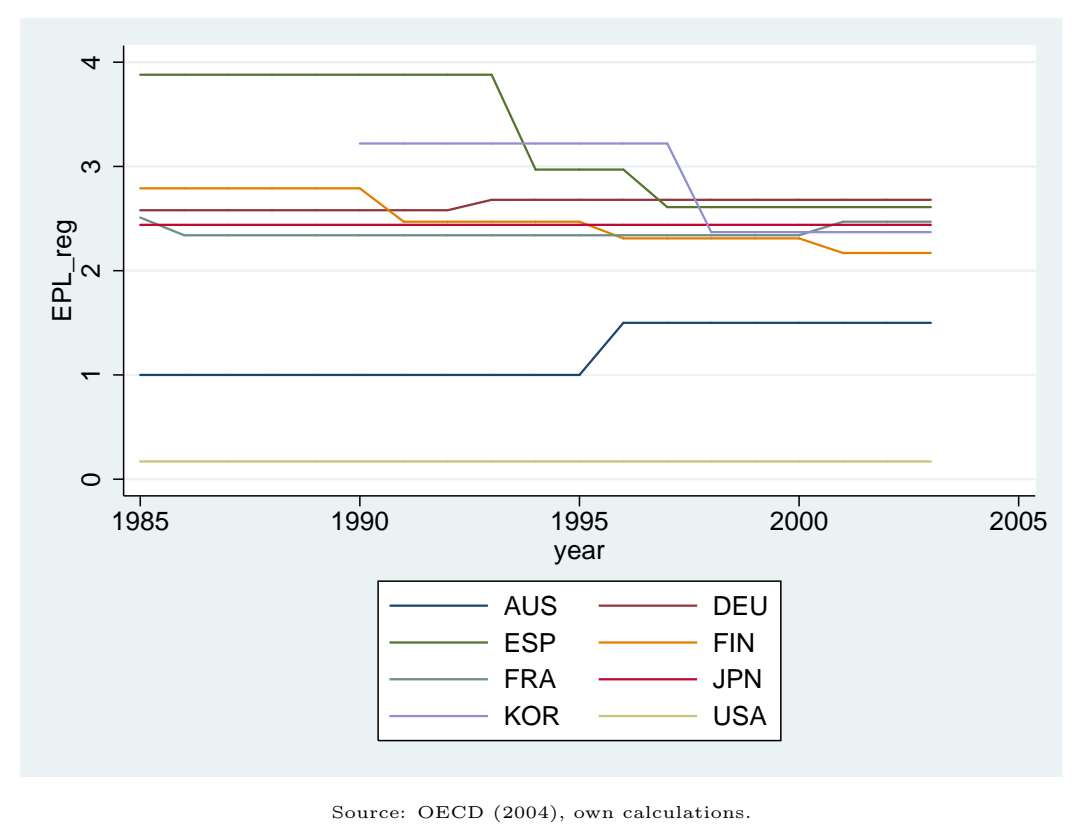

Figure 2 shows the development of regulation in the atypical employment sector between 1985 and 2003. There is substantial variation between the countries, even larger than in the regular employment sector. We also see substantial deregulation in some countries (Germany, Japan and to some extent Korea), while there has been no change in countries that already had a low level of regulation at the beginning of the time span of the sample (Australia, Finland, USA). In France, regulation has increased, while in Spain, an increase followed a decrease in regulation. Hence, there seems to be no clear trend in the development of regulation in this sector.

\subsection{Globalization: Economic, Political and Social Dimensions}

Globalization is measured by the annual KOF Index of Globalization developed by Dreher (2006), which measures the degree of globalization from 1970 onwards, on a 0 to 100 scale. Its three sub-indices cover a country's economic, political, and social dimensions of globalization. All three dimensions contribute with equal weights to the overall index of globalization. ${ }^{16}$

${ }^{16}$ The index is now widely used, e.g. by Gemmell et al. (2008), Lamo et al. (2008) and Aidt and Gassebner (2010). 
Figure 2: Employment protection, atypical employment, selected countries, 1985-2003

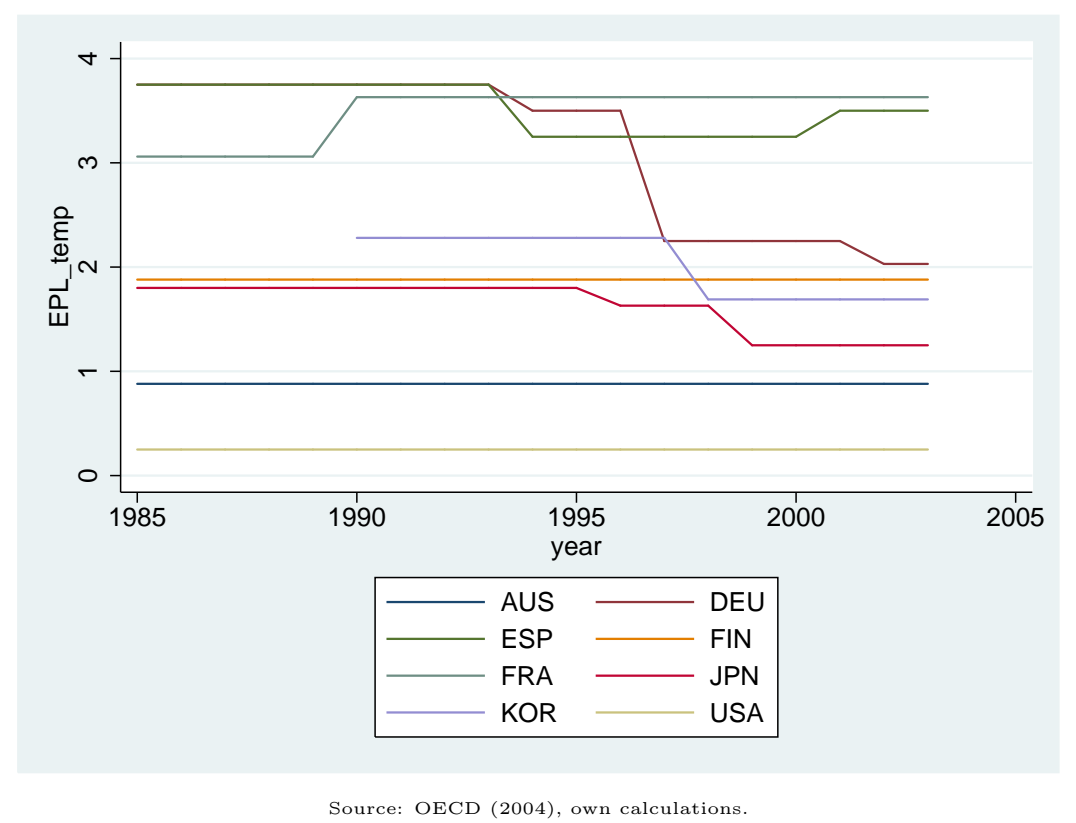

Economic globalization includes not only the traditional aspects of cross-national flows of goods and services, but also measures of foreign investment (direct, portfolio), the absence of traditional barriers to trade and capital flows, as well as indicators of internationalization of a country's labor force. The political dimension of globalization is captured mainly by a country's number of memberships in international organizations, foreign embassies, and participations in UN peace missions. Finally, social globalization aims at measuring the spread and exchange of ideas, values, images and people. This aspect is captured by, for example, fast food chain prevalence (as indicator of U.S. culture influence), cross-national trade in books and newspapers, but also international tourism and number of internet users. Overall, aspects of social globalization can be grouped into 'personal contacts', 'information flow' and 'cultural proximity' (see also Dreher and Gaston, 2005).

Table 8 of Section 8 at the end of this paper provides descriptive statistics of the globalization measures in our sample of OECD countries, which all endorse the principles of free trade. The index of economic globalization has a considerably large mean of 73.5 points, but ranges still from 37.8 to 96.0 , resulting in a standard deviation of 12.5 . The development of globalization is not uniform in our sample: the speed by which a nation opened itself economically (as well as politically and socially) varies by country and world region, even among OECD member states which share, by definition of their membership, similar economic and political institutions.

Figure 3 shows the development of overall globalization and its three sub-categories for the 
same selection of countries as in Figures 1 and 2 from 1970 to 2003. Generally, we see substantial variation both between countries and within the time series, and a trend towards a higher level of globalization in all four panels. Except for social globalization, Japan seems to be far less internationally integrated than the rest of the countries. The US, starting with a relatively high level of globalization in all fields, is overtaken by all countries except for Japan in overall, economic, and political globalization over time. At the end of the period studied, even the former communistblock Czech Republic is more globalized in these fields, after a rapid catch-up during the nineties, than the US. Also Spain has experienced a substantial increase in international integration, both in absolute terms and relative to other countries. The Scandinavian countries show the highest level of overall, economic, and political globalization. Somewhat different from the other three panels is the graph for political globalization. Here, there is no time trend, and large variation in the time series for some of the countries. Here, however, the US is in the top position both at the beginning and at the end of the time series, while the Scandinavian countries are only in the midfield. The pattern for Spain and the Czech Republic is the same as in the other fields of globalization: A large absolute and relative increase in social globalization. Hence, there is not only substantial variation within the time series and across countries, there is also variation over time in the relative levels of globalization between the single countries, i.e. variation in the data is not only cross-sectional (constant distance between lines), but also across time (local differences in steepness), even when the model includes time fixed effects that take out the common development pattern.

\subsection{Controlling Variables}

In this analysis, as controlling variables we also employ data on unemployment rate, unemployment benefit spending (as share of gross domestic product (GDP)), population size, and national income (GDP), its 5-year growth rate, all obtained from the World Bank's World Development Indicator (WDI) database (World Bank, 2009). Furthermore, we measure the political leaning of the government in two different ways. First, we use a dummy indicating a left-wing government, which has been constructed from data available in the updated version (2005) of Beck et al. (2001). Second, we use the index developed in Bjørnskov (2008), which is based on the number of seats held by the parties in government and, thus, continuous. This index of government ideology ranges between the values -1 and 1 , where -1 indicates a fully left-wing government and 1 a right-wing government. Although the maximum number of observations is 486 country-years, due to some missing values in the remaining explanatory variables, we obtain an unbalanced panel with a maximum of 480 observations. The unemployment rate and unemployment spending (in $\log$ ) are used to proxy pressure to loosen employment protection emerging from the situation in the domestic labor market. We furthermore control for the five year GDP growth rate and national income, as faster growing and richer countries are more likely to have strong unions, possibly leading to 
Figure 3: Globalization and its sub-components, 1970-2003
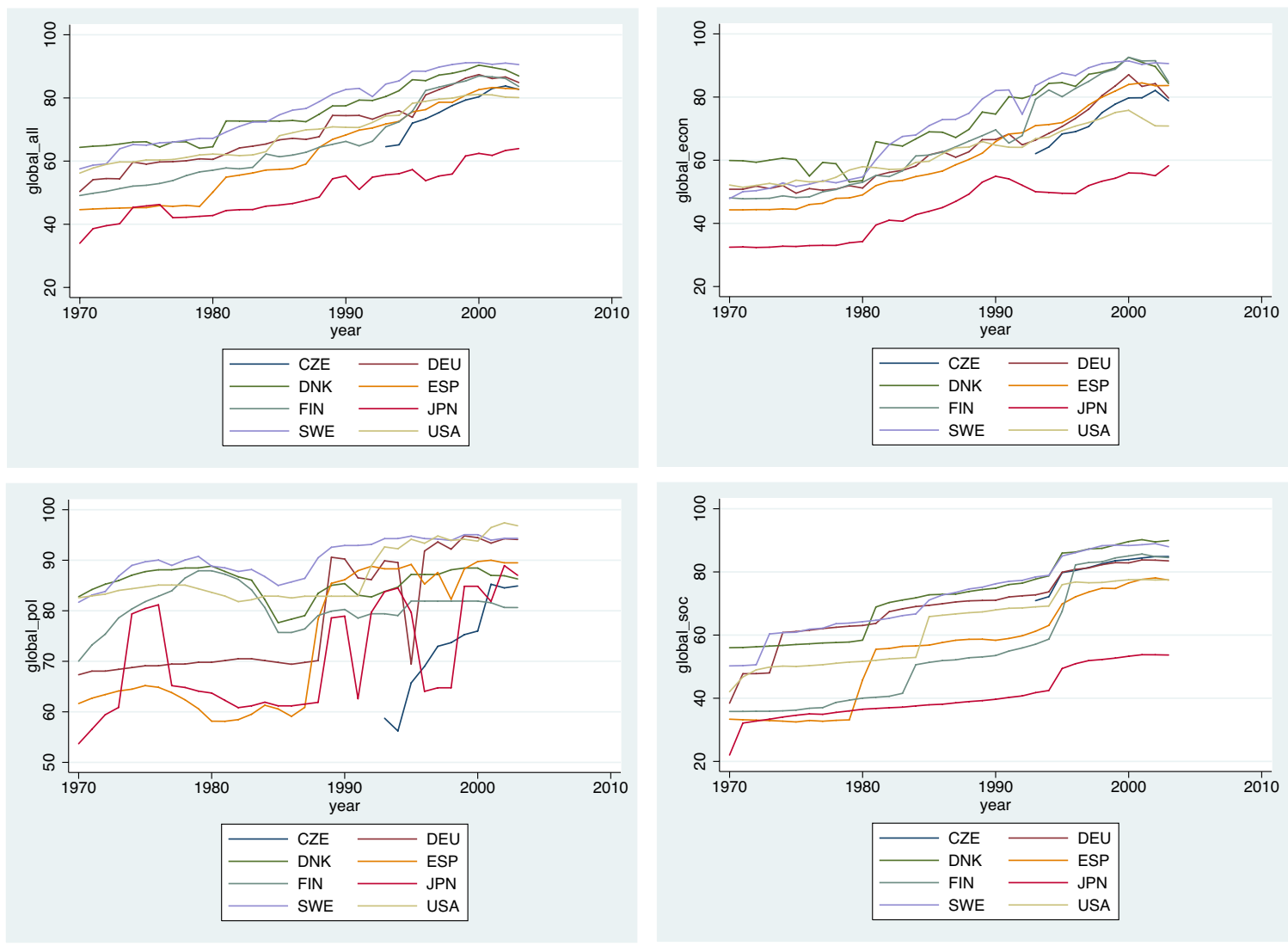

Source: KOF Index of Globalization (Dreher, 2006), own calculations.

stricter employment protection (see Dreher and Gaston, 2005; Wallerstein and Western, 2000). ${ }^{17}$ We use the five year growth rate as we want to control for structural aspects of the economy. The business cycle is controlled for by the unemployment rate and year fixed effects. We also include the logarithm of the population size that accounts for the size of the domestic market, with a larger domestic demand possibly implying less 'need' for domestic firms to expand internationally, lowering competitive pressure by foreign competitors on domestic labor standards. The exact definitions of the variables in the empirical model and descriptive statistics are provided in Table 8 .

${ }^{17}$ The direct inclusion of unionization as a controlling variable would reduce the sample size from 26 to 20 countries. We introduce unionization in a separate regression as a robustness check later. The main results remain the same. 


\subsection{Model}

In our model we view employment protection legislation in country $i$ at time $t\left(E P L_{i t}\right)$ as a function of globalization in the same country $\left(G L O B_{i t}\right)$, and a set of country-specific controlling factors $\left(X_{i t}\right)$ that might be correlated with both the focal variable and the dependent variable. Country $\left(F E_{i}\right)$ and year $\left(T_{t}\right)$ fixed effects account for unobserved country heterogeneity due to time-invariant national characteristics (such as certain labor market regulations and features of the insurance system) and year-specific (but country-unspecific) factors (such as world-wide economic shocks). A preliminary Hausman test rejected the random effects specification in favor of the fixed effects model, which we employ. An F-test of joint significance indicates that the year effects should not be omitted from the equation. ${ }^{18}$ An error term $\left(\epsilon_{i t}\right)$ completes the model.

Potential simultaneity might bias the estimated coefficient vector. We address this issue by employing country fixed effects and lagging the explanatory variables by two periods. ${ }^{19}$ This specific lag structure is chosen on theoretical grounds, particularly because in most OECD countries the legislature period is four years, so that a 2-year lag might account for the duration of the legislating process and politicians' response time to changes in their party majorities triggered by new economic developments, particularly changes in the degree of globalization. Furthermore, as robustness test for the effects of globalization we estimate a more parsimonious model that excludes some of the potentially endogenous determinants. The complete model looks as follows:

$$
E P L_{i t}=\alpha+\beta G L O B_{i t-2}+\gamma X_{i t-2}+F E_{i}+T_{t}+\epsilon_{i t},
$$

where $E P L_{i t}$ denotes the different indices of employment protection, and $G L O B_{i t-2}$ is the respective (sub-)index of globalization. The vector $X_{i t-2}$ contains the controlling variables, $F E_{i}$ and $T_{t}$ represent country and time fixed effects, $\epsilon_{i t}$ is the error term, $\alpha$ is a constant, and $\beta$ and $\gamma$ are parameters.

\section{Results}

\subsection{Results}

In general, we find that globalization exerts a significant effect on employment protection. In line with our reasoning, we find these effects to differ in magnitude and significance between the different dimensions of globalization as well as between the different segments of the labor market.

According to Table 1, column 1, the protection of regular employment appears lowered by overall globalization, while column 1 of Table 2 reveals that the net effect of overall globalization on protection of the temporarily employed is actually positive. Given the relatively small size of the

\footnotetext{
${ }^{18} \mathrm{~A}$ Tobit model would yield inconsistent estimates due to the inclusion of fixed-effects.

${ }^{19}$ Lack of suitable instruments does not allow for testing the exogeneity assumption.
} 
Table 1: Globalization and protection of regularly employed, 1985-2003

\begin{tabular}{|c|c|c|c|c|c|}
\hline & (1) & (2) & (3) & (4) & (5) \\
\hline $\log G D P(-2)$ & -0.296 & -0.146 & $-0.476^{*}$ & $-0.534^{* *}$ & $-0.731^{* * *}$ \\
\hline & [1.09] & {$[0.54]$} & [1.82] & {$[2.02]$} & {$[2.76]$} \\
\hline Log Population (-2) & $\begin{array}{l}2.268^{* * *} * \\
{[5.98]}\end{array}$ & $\begin{array}{l}2.423^{* * *} \\
{[6.42]}\end{array}$ & $\begin{array}{l}2.399^{* * *} \\
{[6.34]}\end{array}$ & $\begin{array}{l}2.652^{* * *} \\
{[6.98]}\end{array}$ & $\begin{array}{l}2.489^{* * *} \\
{[6.31]}\end{array}$ \\
\hline Unemployment rate (-2) & $\begin{array}{l}0.007 \\
{[1.27]}\end{array}$ & $\begin{array}{c}0.010^{*} \\
{[1.82]}\end{array}$ & $\begin{array}{c}0.011^{*} \\
{[1.93]}\end{array}$ & $\begin{array}{l}0.003 \\
{[0.59]}\end{array}$ & $\begin{array}{l}0.004 \\
{[0.78]}\end{array}$ \\
\hline Log unemployment spending (-2) & $\begin{array}{c}-0.077^{* *} \\
{[2.56]}\end{array}$ & $\begin{array}{c}-0.086 * * * \\
{[2.81]}\end{array}$ & $\begin{array}{c}-0.113 * * * \\
{[3.73]}\end{array}$ & $\begin{array}{c}-0.069^{* *} \\
{[2.22]}\end{array}$ & $\begin{array}{c}-0.090 * * * \\
{[2.89]}\end{array}$ \\
\hline GDP growth (-2) & $\begin{array}{l}0.012 \\
{[0.82]}\end{array}$ & $\begin{array}{l}0.008 \\
{[0.53]}\end{array}$ & $\begin{array}{l}0.022 \\
{[1.50]}\end{array}$ & $\begin{array}{c}0.025^{*} \\
{[1.73]}\end{array}$ & $\begin{array}{c}0.032^{* *} \\
{[2.18]}\end{array}$ \\
\hline Left-wing govt. (-2) & $\begin{array}{c}0.056^{* * * *} \\
{[2.99]}\end{array}$ & $\begin{array}{c}0.062^{* * *} * \\
{[3.36]}\end{array}$ & $\begin{array}{c}0.049 * * * \\
{[2.60]}\end{array}$ & $\begin{array}{c}0.062^{* * *} * \\
{[3.24]}\end{array}$ & $\begin{array}{c}0.049^{* *} \\
{[2.55]}\end{array}$ \\
\hline Globalization, overall (-2) & $\begin{array}{c}-0.018^{* * *} \\
{[4.95]}\end{array}$ & & & & \\
\hline Economic glob. (-2) & & $\begin{array}{c}-0.012^{* * *} \\
{[4.97]}\end{array}$ & $\begin{array}{c}-0.011^{* * *} \\
{[4.51]}\end{array}$ & & \\
\hline Political glob. (-2) & & $\begin{array}{c}-0.008^{* * *} \\
{[4.30]}\end{array}$ & & $\begin{array}{c}-0.007 * * * \\
{[3.80]}\end{array}$ & \\
\hline Social glob. (-2) & & $\begin{array}{r}-0.001 \\
{[0.61]}\end{array}$ & & & $\begin{array}{c}-0.002 \\
{[1.09]}\end{array}$ \\
\hline Constant & $\begin{array}{c}-21.430 * * * \\
{[4.05]}\end{array}$ & $\begin{array}{c}-24.366^{* * *} \\
{[4.58]}\end{array}$ & $\begin{array}{c}-21.802^{* * *} \\
{[4.10]}\end{array}$ & $\begin{array}{c}-24.507 * * * \\
{[4.54]}\end{array}$ & $\begin{array}{c}-21.486 * * * \\
{[3.87]}\end{array}$ \\
\hline Observations & 401 & 401 & 401 & 401 & 401 \\
\hline Number of countries & 26 & 26 & 26 & 26 & 26 \\
\hline$R$-squared (within) & 0.31 & 0.34 & 0.30 & 0.29 & 0.27 \\
\hline
\end{tabular}

Notes: Dependent variable is the Employment Protection Index for regularly employed workers (OECD, 2004), ranging from 0 to 6 . OLS estimation with country and year fixed effects (not reported). Globalization is measured on a scale ranging from 0 to 100 (Dreher, 2006). Absolute value of t-statistics in brackets. '*', ‘**', '***' denote statistical significance at $10 \%, 5 \%$ and $1 \%$ levels respectively.

atypical employment sector, overall globalization seems to lead to a general decrease of employment protection in the economy, but also to an increase of protection in the atypical sector compared to the regular sector.

For the regularly employed, we find the protection-lowering effect of overall globalization (Table 1, column 1) to be driven by its economic and political dimensions. Both exert a significant negative impact on employment protection - independently as well as when simultaneously included in the regressions (Table 1, columns 2 to 5). Simultaneous inclusion lets us rule out the possibility that one dimension simply proxies the other in the single dimension regressions (Table 1, column 2). Social globalization is found to exert no statistically significant effect. For the regular employment sector, a simple comparison of the estimated coefficients indicates that economic globalization has quantitatively the largest effect on employment protection. The size of the effect is quite considerable: An increase in economic globalization (running from 0 to 100) by 10 score points lowers employment protection by roughly 0.12 points, a change in EPL that could be triggered by e.g. liberalizing the dismissal procedure from one in which a third party approval is required to a regulation according to which only a simple notification of a work council is needed (decreases EPL by 0.15 points).

Taking the results of Table 1 together, mainly economic, but also political globalization appear to weaken the laws protecting regular employment. This finding is in support of traditional 
Table 2: Globalization and protection of atypically employed, 1985-2003

\begin{tabular}{|c|c|c|c|c|c|}
\hline & (1) & (2) & (3) & (4) & (5) \\
\hline \multirow[t]{2}{*}{$\log G D P(-2)$} & $2.891^{* * *}$ & $3.194^{* * *}$ & $3.994^{* * *}$ & $3.234^{* * *}$ & $3.136^{* * *}$ \\
\hline & {$[3.88]$} & {$[4.32]$} & {$[5.53]$} & {$[4.50]$} & {$[4.49]$} \\
\hline \multirow[t]{2}{*}{ Log Population (-2) } & $8.849^{* * *}$ & $8.868^{* * *}$ & $8.175^{* * *}$ & $8.262^{* * *}$ & $9.184^{* * *}$ \\
\hline & [8.47] & [8.53] & [7.84] & [7.97] & [8.82] \\
\hline \multirow{2}{*}{ Unemployment rate (-2) } & 0.000 & 0.014 & 0.011 & 0.006 & 0.005 \\
\hline & {$[0.03]$} & [0.93] & {$[0.76]$} & {$[0.41]$} & {$[0.35]$} \\
\hline \multirow{2}{*}{ Log unemployment spending (-2) } & -0.124 & $-0.188^{* *}$ & -0.123 & -0.139 & -0.135 \\
\hline & [1.50] & {$[2.24]$} & [1.47] & [1.64] & [1.64] \\
\hline \multirow[t]{2}{*}{ GDP growth (-2) } & $-0.076^{*}$ & $-0.086^{* *}$ & $-0.127 * * *$ & $-0.094^{* *}$ & $-0.082^{* *}$ \\
\hline & {$[1.86]$} & {$[2.14]$} & {$[3.19]$} & {$[2.39]$} & {$[2.11]$} \\
\hline \multirow[t]{2}{*}{ Left-wing govt. (-2) } & 0.081 & 0.078 & $0.089^{*}$ & 0.070 & $0.094^{*}$ \\
\hline & {$[1.57]$} & {$[1.52]$} & {$[1.73]$} & {$[1.34]$} & {$[1.86]$} \\
\hline Globalization, overall (-2) & $\begin{array}{c}0.027^{* * * *} \\
{[2.72]}\end{array}$ & & & & \\
\hline \multicolumn{2}{|l|}{ Economic glob. (-2) } & $\begin{array}{c}-0.013^{*} \\
{[1.94]}\end{array}$ & $\begin{array}{c}-0.014^{*} \\
{[1.93]}\end{array}$ & & \\
\hline Political glob. (-2) & & $\begin{array}{c}0.009^{*} \\
{[1.75]}\end{array}$ & & $\begin{array}{c}0.011^{* *} \\
{[2.20]}\end{array}$ & \\
\hline Social glob. (-2) & & $\begin{array}{c}0.020^{* * * *} \\
{[3.78]}\end{array}$ & & & $\begin{array}{c}0.021^{* * *} \\
{[3.85]}\end{array}$ \\
\hline Constant & $\begin{array}{c}-132.640^{* * * *} \\
{[9.11]}\end{array}$ & $\begin{array}{c}-137.581^{* * *} \\
{[9.38]}\end{array}$ & $\begin{array}{c}-131.973^{* * *} \\
{[9.02]}\end{array}$ & $\begin{array}{c}-127.800 * * * \\
{[8.68]}\end{array}$ & $\begin{array}{c}-141.235^{* * *} \\
{[9.64]}\end{array}$ \\
\hline Observations & 401 & 401 & 401 & 401 & 401 \\
\hline Number of countries & 26 & 26 & 26 & 26 & 26 \\
\hline$R$-squared (within) & 0.43 & 0.45 & 0.42 & 0.42 & 0.44 \\
\hline
\end{tabular}

Notes: Dependent variable is the Employment Protection Index for atypically employed workers (OECD, 2004), ranging from 0 to 6 . OLS estimation with country and year fixed effects (not reported). Globalization is measured on a scale ranging from 0 to 100 (Dreher, 2006). Absolute value of t-statistics in brackets. '*', '**, '***, denote statistical significance at $10 \%, 5 \%$ and $1 \%$ levels respectively.

and political economy models of international trade suggesting that fiercer international market competition makes domestic firms lobby for more domestic labor market flexibility.

In contrast, Table 2 shows that protection of fixed-term and temporary-work-agency employed workers ('atypical contracts') is actually increased by globalization, measured by its general index (column 1). However, this time it is not the economic dimension of globalization that gives rise to this finding, which again exerts a negative effect (Table 2, column 3). Instead, it is the social and political dimensions of globalization that strengthen employment protection (Table 2, columns 4 and 5), outweighing the labor standards lowering effect of economic globalization. Again, an increase in political globalization of 10 points would result in an substantial increase in EPL for 'atypical' forms of employments that equaled, for example, restricting the number of contract renewals, or changing the maximum of cumulated contract duration from 'no limitation' to '24 months' $(=+0.125$ points). Column 2 includes all three dimensions of globalization. It confirms the preceding single-dimension analyses, i.e. the positive net effect of overall globalization on protection of temporary employment, being driven entirely by its non-economic dimensions (social and political).

Turning to the effects of our controlling variables, we observe some similarities and some dissimilarities across the two different labor market segments. For both segments, Tables 1 and 2 show that populous countries tend to protect their workers better, while the unemployment rate seems to exert no effect. A larger burden of unemployment spending in the economy exerts a pressure to 
deregulate the labor market - particularly for the regularly employed. ${ }^{20}$ Furthermore, as countries grow richer, protection of temporarily employed workers increases, as predicted, while the protection of regularly employed is decreased. Economic performance in the past five years, as measured by the five year growth rate of GDP, seems to have no large influence on protection in the regular sector, while lo-wering protection in the atypical sector. For regular employment, supporting our reasoning above, we also find that left-wing governments tend to support a higher level of employment protection. In tendency, this effect is also observable for temporary employment, albeit statistically weaker. The findings are similar when we employ a continuous variable as alternative measure of government ideology instead of the dummy variable (Tables 3 and 4).

Taking the results of Table 2 altogether, we find that globalization in its social and political dimensions put an upward pressure on protection of workers with 'atypical' contracts. In contrast, the economic dimension appears to decrease labor standards, yielding a positive net effect of globalization on labor protection in this sector.

Combining the results of Tables 1 and 2, we find that economic globalization decreases labor protection. In contrast, political (and social) globalization influence protection negatively in the regular sector, but positively in the atypical sector, in sum leading to a relative increase of protection in the latter sector compared to protection in the first.

\subsection{Robustness}

Our main results are robust to several changes in the specification of the regression and in the sample. The Tables presenting the results of the robustness check can be found in Section 8 at the end of this paper. We obtain results that are qualitatively similar (in terms of coefficient sizes and direction of influence of globalization measures) if a more parsimonious model is estimated that omits those variables that are potentially endogenous to employment protection, such as the unemployment rate, GDP growth, and left-wing ideology of the government (see Tables 9 and 10). Moreover, the findings are robust to estimating our models with a reduced sample that excludes the former communist countries Czech Republic, Poland, Hungary, and Slovak Republic (see Tables 11 and 12); this test rejects the claim that our findings were driven by transition countries that, from 1991 on, underwent extreme changes in their international economic integration, as discussed in Section 4. The results are also qualitatively unaltered when we take autocorrelation of the residuals into account or when we replace the dichotomous indicator of government ideology with a continuous measure (see Tables 3 and 4 ).

Our results remain also unaltered when we include union density as an additional control variable (see Tables 13 and 14). Again, we find a negative effect of the overall index of globalization on

\footnotetext{
${ }^{20}$ The negative correlation between the generosity of unemployment benefits and employment protection was already reported in OECD (2004, p. 92).
} 
Table 3: Globalization and protection of regularly employed, 1985-2003

\begin{tabular}{|c|c|c|c|c|c|}
\hline & (1) & (2) & (3) & (4) & (5) \\
\hline $\log G D P(-2)$ & 0.024 & 0.174 & -0.216 & -0.235 & -0.449 \\
\hline & {$[0.08]$} & {$[0.60]$} & {$[0.77]$} & {$[0.82]$} & {$[1.57]$} \\
\hline Log Population (-2) & $2.586 * * *$ & $2.691 * * *$ & $2.658 * * *$ & $3.110 * * *$ & $2.879 * * *$ \\
\hline & [6.15] & [6.41] & [6.29] & [7.38] & [6.60] \\
\hline Unemployment rate (-2) & 0.005 & 0.008 & 0.009 & -0.001 & 0.001 \\
\hline & {$[0.88]$} & {$[1.44]$} & {$[1.64]$} & {$[0.17]$} & {$[0.22]$} \\
\hline Log unemployment spending (-2) & $\begin{array}{c}-0.061^{* *} \\
{[2.06]}\end{array}$ & $\begin{array}{c}-0.068^{* *} \\
{[2.24]}\end{array}$ & $\begin{array}{c}-0.102^{* * *} \\
{[3.37]}\end{array}$ & $\begin{array}{r}-0.048 \\
{[1.55]}\end{array}$ & $\begin{array}{l}-0.074^{* *} \\
{[2.42]}\end{array}$ \\
\hline GDP growth (-2) & $\begin{array}{c}-0.004 \\
{[0.28]}\end{array}$ & $\begin{array}{c}-0.009 \\
{[0.59]}\end{array}$ & $\begin{array}{l}0.008 \\
{[0.52]}\end{array}$ & $\begin{array}{l}0.006 \\
{[0.37]}\end{array}$ & $\begin{array}{l}0.015 \\
{[0.96]}\end{array}$ \\
\hline Right-wing govt., continuous (-2) & $\begin{array}{c}-0.102^{* * *} \\
{[3.38]}\end{array}$ & $\begin{array}{l}-0.111^{* * *} \\
{[3.75]}\end{array}$ & $\begin{array}{c}-0.088^{* * *} \\
{[2.94]}\end{array}$ & $\begin{array}{c}-0.091^{* * * *} \\
{[3.01]}\end{array}$ & $\begin{array}{c}-0.077^{* *} \\
{[2.51]}\end{array}$ \\
\hline Globalization, overall (-2) & $\begin{array}{c}-0.019 * * * \\
{[5.16]}\end{array}$ & & & & \\
\hline Economic glob. (-2) & & $\begin{array}{c}-0.013^{* * *} \\
{[5.16]}\end{array}$ & $\begin{array}{c}-0.012^{* * *} \\
{[4.63]}\end{array}$ & & \\
\hline Political glob. (-2) & & $\begin{array}{c}-0.008^{* * *} \\
{[4.43]}\end{array}$ & & $\begin{array}{c}-0.007 * * * \\
{[3.86]}\end{array}$ & \\
\hline Social glob. (-2) & & $\begin{array}{c}-0.002 \\
{[0.96]}\end{array}$ & & & $\begin{array}{c}-0.002 \\
{[1.23]}\end{array}$ \\
\hline Constant & $\begin{array}{c}-27.775^{* * *} \\
{[4.61]}\end{array}$ & $\begin{array}{c}-30.053^{* * *} \\
{[5.00]}\end{array}$ & $\begin{array}{c}-26.953^{* * * *} \\
{[4.43]}\end{array}$ & $\begin{array}{c}-32.305^{* * *} \\
{[5.22]}\end{array}$ & $\begin{array}{c}-28.043^{* * *} \\
{[4.47]}\end{array}$ \\
\hline Observations & 396 & 396 & 396 & 396 & 396 \\
\hline Number of countries & 25 & 25 & 25 & 25 & 25 \\
\hline$R$-squared (within) & 0.32 & 0.35 & 0.31 & 0.30 & 0.27 \\
\hline
\end{tabular}

Notes: Dependent variable is the Employment Protection Index for regularly employed workers (OECD, 2004), ranging from 0 to 6. OLS estimation with country and year fixed effects (not reported). Globalization is measured on a scale ranging from 0 to 100 (Dreher, 2006). Political orientation of the government is measured by the continuous ideology index developed by Bjørnskov (2008). Absolute value of t-statistics in brackets. '*, '**, '***, denote statistical significance at 10\%, 5\% and 1\% levels respectively. 
Table 4: Globalization and protection of atypically employed, 1985-2003

\begin{tabular}{|c|c|c|c|c|c|}
\hline & (1) & (2) & (3) & (4) & (5) \\
\hline \multirow[t]{2}{*}{$\log G D P(-2)$} & $2.820^{* * *}$ & $2.990^{* * *}$ & $4.006^{* * *}$ & $3.181^{* * *}$ & $3.217^{* * *}$ \\
\hline & {$[3.50]$} & [3.73] & [5.12] & [4.08] & {$[4.21]$} \\
\hline \multirow[t]{2}{*}{ Log Population (-2) } & $9.995 * * *$ & $9.624 * * *$ & $9.024 * * *$ & $9.075 * * *$ & $10.130^{* * *}$ \\
\hline & {$[8.59]$} & {$[8.24]$} & {$[7.70]$} & {$[7.89]$} & {$[8.72]$} \\
\hline \multirow[t]{2}{*}{ Unemployment rate (-2) } & -0.017 & -0.003 & -0.004 & -0.007 & -0.012 \\
\hline & {$[1.18]$} & {$[0.17]$} & {$[0.24]$} & {$[0.50]$} & {$[0.86]$} \\
\hline \multirow[t]{2}{*}{ Log unemployment spending (-2) } & -0.101 & $-0.169^{* *}$ & -0.094 & -0.131 & -0.100 \\
\hline & [1.22] & {$[2.01]$} & [1.13] & [1.55] & [1.22] \\
\hline \multirow[t]{2}{*}{ GDP growth (-2) } & $-0.110^{* *}$ & $-0.112^{* *}$ & $-0.158 * * *$ & $-0.124 * * *$ & $-0.124 * * *$ \\
\hline & {$[2.51]$} & {$[2.58]$} & {$[3.67]$} & {$[2.87]$} & {$[2.93]$} \\
\hline \multirow{2}{*}{ Right-wing govt., continuous (-2) } & 0.120 & 0.114 & 0.061 & 0.108 & 0.096 \\
\hline & {$[1.44]$} & {$[1.39]$} & {$[0.73]$} & {$[1.30]$} & {$[1.18]$} \\
\hline Globalization, overall (-2) & $\begin{array}{c}0.032^{* * * *} \\
{[3.15]}\end{array}$ & & & & \\
\hline \multicolumn{2}{|l|}{ Economic glob. (-2) } & $\begin{array}{c}-0.010 \\
{[1.36]}\end{array}$ & $\begin{array}{r}-0.011 \\
{[1.52]}\end{array}$ & & \\
\hline \multicolumn{2}{|l|}{ Political glob. (-2) } & $\begin{array}{c}0.013^{* *} \\
{[2.47]}\end{array}$ & & $\begin{array}{c}0.015^{* * * *} \\
{[2.78]}\end{array}$ & \\
\hline \multicolumn{2}{|l|}{ Social glob. (-2) } & $\begin{array}{c}0.019 * * * \\
{[3.47]}\end{array}$ & & & $\begin{array}{c}0.019^{* * *} \\
{[3.57]}\end{array}$ \\
\hline Constant & $\begin{array}{c}-144.884^{* * *} \\
{[8.69]}\end{array}$ & $\begin{array}{c}-141.520^{* * *} \\
{[8.45]}\end{array}$ & $\begin{array}{c}-141.360^{* * *} \\
{[8.37]}\end{array}$ & $\begin{array}{c}-136.282^{* * *} * \\
{[8.06]}\end{array}$ & $\begin{array}{c}-149.233^{* * *} \\
{[8.94]}\end{array}$ \\
\hline Observations & 396 & 396 & 396 & 396 & 396 \\
\hline Number of countries & 25 & 25 & 25 & 25 & 25 \\
\hline$R$-squared (within) & 0.43 & 0.45 & 0.42 & 0.43 & 0.43 \\
\hline
\end{tabular}

Notes: Dependent variable is the Employment Protection Index for atypically employed workers (OECD, 2004), ranging from 0 to 6. OLS estimation with country and year fixed effects (not reported). Globalization is measured on a scale ranging from 0 to 100 (Dreher, 2006). Political orientation of the government is measured by the continuous ideology index developed by Bjørnskov (2008). Absolute value of t-statistics in brackets. '*, '**, '***, denote statistical significance at 10\%, 5\% and 1\% levels respectively. 
protection of regularly employed workers and a zero net effect for the temporary-contract sector. Turning to the sub-indices of globalization, in line with our previous findings, the coefficients of economic, political, and social globalization turn out negative and significant for the regular employment sector. For the atypical-contract sector, we find again that the negative effect of economic globalization is compensated by a positive effect of political globalization.

\section{The Role of Government Ideology}

The impact exerted by globalization might not only be direct, but also indirect. More specifically, the effects of globalization that weaken employment protection might be amplified through the ideology of the incumbent government. Put differently, we can expect interplays between the three dimensions of globalization and government ideology. In the following we test this conjecture for a right-wing ideology of the government, which was previously found to lower employment protection, at least for the regularly employed.

Tables 5 and 6 show the results of this exercise. We employ the continuous measure of rightwing government ideology by Bjørnskov (2008) in place of the previously employed dichotomous indicator for left-wing governments. The models with the odd numbers $(1,3$, and 5$)$ report the findings for the baseline specifications of Tables 3 and 4, while the models with the even numbers $(2,4$, and 6$)$ add interaction terms to the empirical model.

For the regularly employed (Table 5), only the interaction for economic globalization is significant; the negative sign indicates that right-wing government ideology aggravates the protectionlowering impact of economic globalization: the government responds the stronger to the forces of economic globalization, the more right-wing it is (column 4). Such interactions with government ideology are not observable for the political and social dimensions of globalization (columns 6 and 8).

For the temporarily employed (Table 6), we observe a positive and significant interaction between political globalization and right-wing ideology (column 6), while the remaining interaction terms are insignificant. Obviously, right-wing government ideology aggravates the protectionenhancing effect of political globalization: conservative governments are more likely to seek international co-operative solutions to protect the atypically employed, possibly to avoid a reduction in relative competitiveness by ensuring internationally harmonized labor standards.

In sum, for the regularly employed, a right-wing government is more likely to give in to the pressure to deregulate exerted by economic globalization than a leftist one, while they make better use of political globalization to protect workers with atypical contracts. These results suggest that the 'policy mixture' strategy (see Section 3) - appeasing the workforce and unions by stronger protecting the economically far less important atypical contract employees, while reducing the employment protection of the regularly employed - is a policy particularly pursued by right-wing governments. 
Table 5: Interaction between globalization and government ideology for regular employment, 1985-2003

\begin{tabular}{|c|c|c|c|c|c|c|c|c|}
\hline & (1) & (2) & (3) & (4) & (5) & (6) & (7) & $(8)$ \\
\hline $\log G D P(-2)$ & 0.024 & 0.024 & -0.216 & -0.259 & -0.235 & -0.221 & -0.449 & -0.440 \\
\hline Log Population (-2) & $\begin{array}{l}{[0.08]} \\
2.586^{* * *}\end{array}$ & $\begin{array}{l}{[0.08]} \\
2.585^{* * *}\end{array}$ & $\begin{array}{l}{[0.77]} \\
2.658^{* * *}\end{array}$ & $2.842^{* * * *}$ & $\begin{array}{c}{[0.82]} \\
3.110^{*} * *\end{array}$ & $\begin{array}{c}{[0.77]} \\
3.102 * * *\end{array}$ & $\begin{array}{c}{[1.57]} \\
2.879 * * *\end{array}$ & $\begin{array}{c}{[1.53]} \\
2.842 * * *\end{array}$ \\
\hline & {$[6.15]$} & {$[6.07]$} & $\begin{array}{l}2.000 \\
{[6.29]}\end{array}$ & {$[6.56]$} & $\begin{array}{l}0.110 \\
{[7.38]}\end{array}$ & {$[7.35]$} & {$[6.60]$} & {$[6.47]$} \\
\hline Unemployment rate (-2) & $\begin{array}{l}0.005 \\
{[0.88]}\end{array}$ & $\begin{array}{l}0.005 \\
{[0.88]}\end{array}$ & $\begin{array}{l}0.009 \\
{[1.64]}\end{array}$ & $\begin{array}{l}0.009 \\
{[1.61]}\end{array}$ & $\begin{array}{l}-0.001 \\
{[0.17]}\end{array}$ & $\begin{array}{l}-0.001 \\
{[0.15]}\end{array}$ & $\begin{array}{l}0.001 \\
{[0.22]}\end{array}$ & $\begin{array}{l}0.001 \\
{[0.23]}\end{array}$ \\
\hline Log unemployment spending (-2) & $\begin{array}{c}-0.061^{* *} \\
{[2.06]}\end{array}$ & $\begin{array}{c}-0.061^{* *} \\
{[2.05]}\end{array}$ & $\begin{array}{c}-0.102^{* * * *} \\
{[3.37]}\end{array}$ & $\begin{array}{c}-0.100^{* * * *} \\
{[3.31]}\end{array}$ & $\begin{array}{l}-0.048 \\
{[1.55]}\end{array}$ & $\begin{array}{l}-0.051 \\
{[1.62]}\end{array}$ & $\begin{array}{c}-0.074^{* *} \\
{[2.42]}\end{array}$ & $\begin{array}{c}-0.075^{* *} \\
{[2.44]}\end{array}$ \\
\hline GDP growth (-2) & $\begin{array}{c}-0.004 \\
{[0.28]}\end{array}$ & $\begin{array}{l}-0.004 \\
{[0.28]}\end{array}$ & $\begin{array}{l}0.008 \\
{[0.52]}\end{array}$ & $\begin{array}{l}0.011 \\
{[0.72]}\end{array}$ & $\begin{array}{l}0.006 \\
{[0.37]}\end{array}$ & $\begin{array}{l}0.005 \\
{[0.30]}\end{array}$ & $\begin{array}{l}0.015 \\
{[0.96]}\end{array}$ & $\begin{array}{l}0.014 \\
{[0.89]}\end{array}$ \\
\hline Right-wing govt., continuous (-2) & $\begin{array}{c}-0.102^{* * * *} \\
{[3.38]}\end{array}$ & $\begin{array}{c}-0.102 \\
{[0.50]}\end{array}$ & $\begin{array}{c}-0.088^{* * * *} \\
{[2.94]}\end{array}$ & $\begin{array}{l}0.331 \\
{[1.41]}\end{array}$ & $\begin{array}{c}-0.091^{* * *} \\
{[3.01]}\end{array}$ & $\begin{array}{l}-0.177 \\
{[1.13]}\end{array}$ & $\begin{array}{c}-0.077^{* *} \\
{[2.51]}\end{array}$ & $\begin{array}{c}-0.179 \\
{[1.26]}\end{array}$ \\
\hline Globalization, overall (-2) & $\begin{array}{c}-0.019 * * * \\
{[5.16]}\end{array}$ & $\begin{array}{c}-0.019 * * * \\
{[5.05]}\end{array}$ & & & & & & \\
\hline Economic glob. (-2) & & & $\begin{array}{c}-0.012 * * * \\
{[4.63]}\end{array}$ & $\begin{array}{c}-0.011^{* * *} \\
{[4.00]}\end{array}$ & & & & \\
\hline Political glob. (-2) & & & & & $\begin{array}{c}-0.007^{* * * *} \\
{[3.86]}\end{array}$ & $\begin{array}{c}-0.008 * * * \\
{[3.85]}\end{array}$ & & \\
\hline Social glob. (-2) & & & & & & & $\begin{array}{c}-0.002 \\
{[1.23]}\end{array}$ & $\begin{array}{c}-0.003 \\
{[1.40]}\end{array}$ \\
\hline Globalization (-2) * right-wing govt. (-2) & & $\begin{array}{l}0.000 \\
{[0.00]}\end{array}$ & & $\begin{array}{c}-0.006^{*} \\
{[1.79]}\end{array}$ & & $\begin{array}{l}0.001 \\
{[0.55]}\end{array}$ & & $\begin{array}{l}0.001 \\
{[0.74]}\end{array}$ \\
\hline Constant & $\begin{array}{c}-27.775^{* * *} \\
{[4.61]}\end{array}$ & $\begin{array}{c}-27.773^{* * *} \\
{[4.58]}\end{array}$ & $\begin{array}{c}-26.953^{* * *} \\
{[4.43]}\end{array}$ & $\begin{array}{c}-28.896^{* * *} \\
{[4.69]}\end{array}$ & $\begin{array}{c}-32.305^{* * *} \\
{[5.22]}\end{array}$ & $\begin{array}{c}-32.315^{* * *} \\
{[5.22]}\end{array}$ & $\begin{array}{c}-28.043^{* * *} \\
{[4.47]}\end{array}$ & $\begin{array}{c}-27.642^{* * * *} \\
{[4.39]}\end{array}$ \\
\hline $\begin{array}{l}\text { Observations } \\
\text { Number of countries }\end{array}$ & $\begin{array}{c}396 \\
25\end{array}$ & $\begin{array}{c}396 \\
25\end{array}$ & $\begin{array}{c}396 \\
25\end{array}$ & $\begin{array}{l}396 \\
25\end{array}$ & $\begin{array}{l}396 \\
25\end{array}$ & $\begin{array}{l}396 \\
25\end{array}$ & $\begin{array}{l}396 \\
25\end{array}$ & $\begin{array}{l}396 \\
25\end{array}$ \\
\hline$R$-squared (within) & 0.32 & $\begin{array}{c}25 \\
0.32\end{array}$ & $\begin{array}{c}25 \\
0.31\end{array}$ & $\begin{array}{c}25 \\
0.32\end{array}$ & $\begin{array}{c}25 \\
0.30\end{array}$ & $\begin{array}{c}25 \\
0.30\end{array}$ & $\begin{array}{c}25 \\
0.27\end{array}$ & $\begin{array}{c}25 \\
0.27\end{array}$ \\
\hline
\end{tabular}

Notes: Dependent variable is the Employment Protection Index for regularly employed workers (OECD, 2004), ranging from 0 to 6. OLS estimation with country and year fixed effects (not reported). Globalization is measured on a scale ranging from 0 to 100 (Dreher, 2006). Political orientation of the government is measured by the continuous ideology index developed by Bjgrnskov (2008). Absolute value of t-statistics in brackets. “*, ‘**, (***) denote statistical significance at $10 \%, 5 \%$ and $1 \%$ levels respectively. 
Table 6: Interaction between globalization and government ideology for atypical employment, 1985-2003

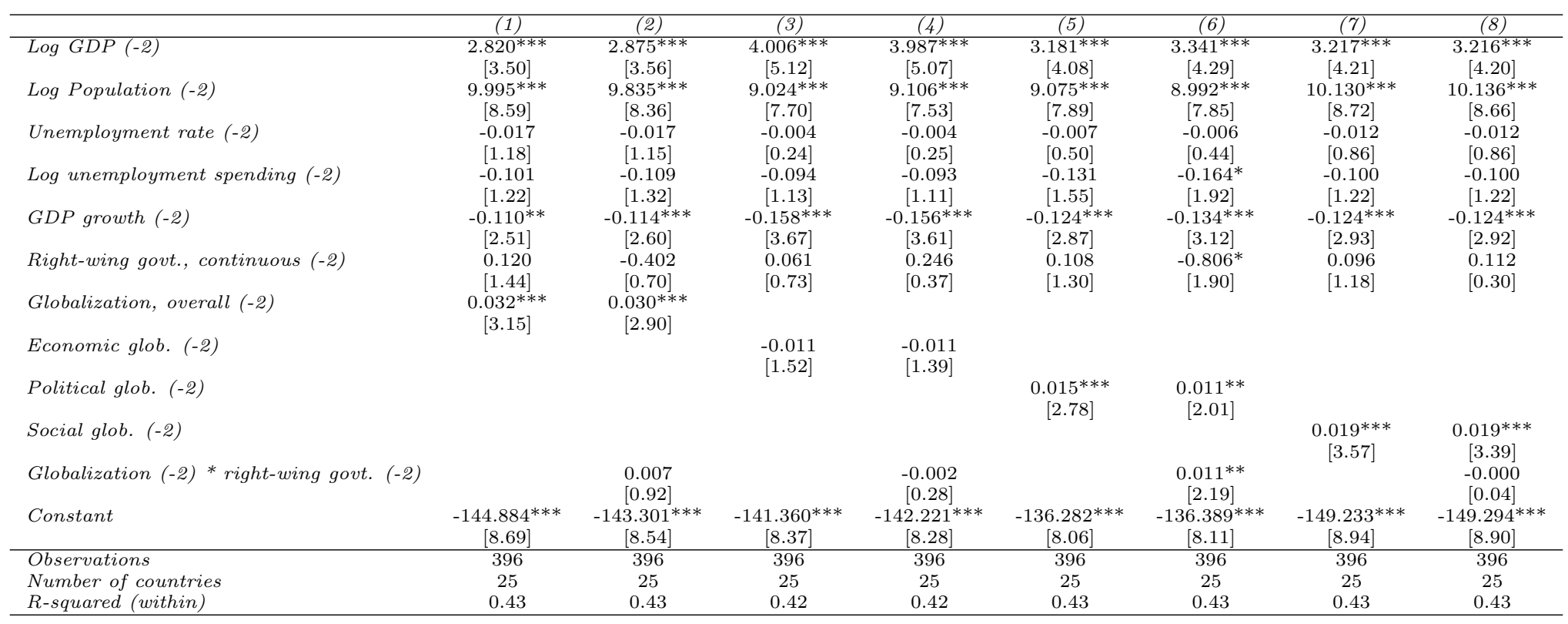

Notes: Dependent variable is the Employment Protection Index for atypically employed workers (OECD, 2004), ranging from 0 to 6. OLS estimation with country and year fixed effects (not reported). Globalization is measured on a scale ranging from 0 to 100 (Dreher, 2006). Political orientation of the government is measured by the continuous ideology index developed by Bjornskov (2008). Absolute value of t-statistics in brackets. '*, "**, ‘***) denote statistical significance at $10 \%, 5 \%$ and $1 \%$ levels respectively. 


\section{Conclusion}

In this paper we have empirically investigated whether globalization exerts a downward pressure on the protection of workers' employment conditions. It is the first contribution to account for the various dimensions of globalization, the economic, the political, and the social one. It is also the first analysis to differentiate between regular and atypical employment.

Using a panel of 28 OECD countries from 1985 to 2003, we test for the impact of globalization in its economic, political, and social dimensions on the strictness of employment protection legislation. We reveal that overall globalization lowers employment protection of the regularly employed, but increases that of workers in 'atypical' employment relations. We argue that relatively improving the protection of the economically less important group of short-term workers may serve as symbolic political act by vote-maximizing politicians intending to 'buy' workers' acceptance of labor market liberalization for the regularly employed.

The analysis for the single dimensions of globalization is supportive of this political economy interpretation: We find that it is the economic dimension of globalization, possibly triggering producers' lobbying activities, which lowers employment protection for regularly employed workers, as predicted by international trade models. We also find that political globalization, possibly one of the transmission channels of producer preferences, adds to this downward pressure. However, for workers in atypical employment, the negative effect of economic globalization is more than outweighed by the effects of international political and social integration, where the latter possibly makes the common workers aware of the phenomenon of globalization through international travel and worldwide communication, while political globalization acts as a means of international policy coordination for the harmonization of labor standards.

Furthermore, we find that the effects of globalization are aggravated by domestic political determinants of labor protection: The deregulative influence of economic globalization on the regularly employed is the larger, the more conservative a government is. At the same time, right-wing governments make regulation of the temporary employment sector the stricter, the more the country is globalized in the political dimension. We view the relevance of globalization in its interplay with political leaning for employment protection as support for the political economy interpretation of 'linkage politics', suggesting that particularly right-wing politicians trade off deregulation of one labor market sector against a stronger regulation of the other.

Overall, this analysis suggests that the economic and societal effects of globalization are not as clear-cut as some public discussions may suggest. The common intuition that globalization is detrimental to the well-being of the dependently employed can only be partly supported. It appears that workers in atypical employment contracts, commonly viewed as more vulnerable as compared to the regularly employed, are not negatively affected by the forces exerted by globalization. Furthermore, our interplay analysis also suggests that the process of globalization is used as an argument 
in the political debate, so that, depending on government ideology, government response either aggravates or counteracts the effects of globalization. Our analysis also reveals that this government response does not necessarily follow traditional ideological lines, contradicting common views and simple truths. However, to identify the exact mechanism behind this development in greater detail, further research is needed. 
Aidt, T. S., Gassebner, M., 2010. Do autocratic states trade less? World Bank Economic Review $24(1), 38-76$.

Beck, T., Clarke, G., Groff, A., Keefer, P., Walsh, P., 2001. New tools in comparative political economy: The database of political institutions. World Bank Economic Review 15 (1), 165-176.

Bhagwati, J., Srinivasan, T. N., 1995. Trade and the environment: Does environmental diversity detract form the case for free trade? In: Bhagwati, J., Hudec, R. E. (Eds.), Fair Trade and Harmonization: Prerequisites for Free Trade? Cambridge: MIT Press, pp. 159-223.

Bjørnskov, C., 2008. The growth-inequality association: Government ideology matters. Journal of Development Economics 87 (2), 300-308.

Blau, F. D., Kahn, L. M., 1996. International differences in male wage inequality: Institutions versus market forces. Journal of Political Economy 104 (4), 791-836.

Brown, D. K., 2000. International trade and core labour standards: A survey of the recent literature. OECD Labour Market and Social Policy Occasional Papers 43, OECD, Directorate for Employment, Labour and Social Affairs.

Busse, M., 2004. The determinants of core labour standards: The case of developing countries. Economics Letters 83 (2), 211-217.

Busse, M., Spielmann, C., 2006. Gender inequality and trade. Review of International Economics $14(3), 362-379$.

Cigno, A., Rosati, F. C., Guarcello, L., 2002. Does globalization increase child labor? World Development 30 (9), 1579-1589.

Dewit, G., Görg, H., Montagna, C., 2009. Should I stay or should I go? Foreign direct investment, employment protection and domestic anchorage. Review of World Economics (Weltwirtschaftliches Archiv) 145 (1), 93-110.

Dreher, A., 2006. Does globalization affect growth? Evidence from a new index of globalization. Applied Economics 38 (10), 1091-1110.

Dreher, A., Gaston, N., 2005. Has globalisation really had no effect on unions? Kyklos 60, 165-186.

Fischer, J. A., 2012. The choice of domestic policies in a globalized economy. MPRA Paper 36990, University Library of Munich, Germany.

Fortin, N. M., Lemieux, T., 1997. Institutional changes and rising wage inequality: Is there a linkage? Journal of Economic Perspectives 11 (2), 75-96. 
Franco, A., Winqvist, K., 2002. At the margins of the labor market? Women and men in temporary jobs in Europe. Statistics in Focus 13.

Gemmell, N., Kneller, R., Sanz, I., 2008. Foreign investment, international trade and the size and structure of public expenditures. European Journal of Political Economy 24, 151-171.

Golden, M., 2000. Economic integration and industrial relations: Is increasing openness bad for labor? Working Paper 1.62, University of Berkeley, Center for German and European Studies.

ILO, 2009. Rules of the Game: A Brief Introduction to International Labour Standards (Revised edition 2009). International Labour Organization, Geneva.

Krueger, A., 1996. Observations on international labor standards and trade. NBER Working Papers 5632, National Bureau of Economic Research.

Kucera, D., 2002. Core labour standards and foreign direct investment. International Labour Review $141,3-36$.

Lamo, A., Pérez, J. J., Schuknecht, L., 2008. Public and private sector wages, co-movement and causality. OECD Working Paper Series 963, OECD.

Mayer, W., Riezman, R. G., 1987. Endogenous choice of trade policy instruments. Journal of International Economics 23 (3-4), $377-381$.

OECD, 2000. International trade and core labour standards. Organisation for Economic Cooperation and Development, Paris.

OECD, 2004. OECD Employment Outlook 2004. Organisation for Economic Co-operation and Development, Paris.

OECD, 2009. Economic outlook: Annual and quarterly data. Organisation for Economic Cooperation and Development, Paris.

Petersen, N., 2009. Rational choice or deliberation? Customary international law between coordination and constitutionalization. Journal of Institutional and Theoretical Economics 165 (1), $71-85$.

Protte, B., 2011. Does fleet street shape politics? How newspaper reporting on globalization changes the support for unemployment insurance. mimeo.

Rodrik, D., 1996. Labor standards in international trade: Do they matter and what do we do about them? In: Council, O. D. (Ed.), Emerging Agenda for Global Trade: High Stakes for Developing Countries. Lawrence, Robert Z., Dani Rodrik and John Whalley, Washington, DC, p. 35-79. 
Shelburne, R. C., 2001. An explanation of the international variation in the prevalence of child labour. The World Economy 24 (3), 359-378.

Sinn, H.-W., 2001. Social dumping in the transformation process. NBER Working Papers 8364, National Bureau of Economic Research.

Statistisches Bundesamt, 2009. Niedrigeinkommen und Erwerbstätigkeit: Begleitmaterial zum Pressegespräch am 19. August 2009 in Frankfurt am Main.

Stein, A., 1980. The politics of linkage. Worlds Politics 33, 62-81.

Stern, R. M., 2003. Labor standards and trade agreements. Working Papers 496, Research Seminar in International Economics, University of Michigan.

Tiebout, C. M., 1956. A pure theory of local expenditures. Journal of Political Economy 64 (5), $416-424$.

Wallerstein, M., Western, B., 2000. Unions in decline: What has changed and why? Annual Review of Political Science 3, 355-77.

Walter, S., 2010a. Globalization and the demand-side of politics: How globalization shapes individual perceptions of labor market risk and policy preferences. mimeo.

Walter, S., 2010b. Globalization and the welfare state: Testing the microfoundations of the compensation hypothesis. International Studies Quarterly 54 (2), 403-426.

World Bank, 2009. World Development Indicators. CD-ROM edition. 
8. Tables 
Table 7: Break points of Employment Protection Legislation (EPL) indices

\begin{tabular}{|c|c|c|c|c|c|}
\hline & & Reform description & EPL overall & EPL regular contracts & EPL temp. contracts \\
\hline \multirow[t]{2}{*}{ Australia } & 1996 & $\begin{array}{l}\text { Workplace Relations Act } 1996 \text { set out factors that Aus- } \\
\text { tralian Industrial Relations Commission must have regard } \\
\text { to when determining whether a termination is unfair }\end{array}$ & + & + & $=$ \\
\hline & 2004 & $\begin{array}{l}\text { The scale for employers with } 15 \text { or more employees has } \\
\text { also increased in March } 2004 \text { (the small business exemp- } \\
\text { tion to severance pay has been removed, now requiring } \\
\text { employers with less than } 15 \text { employees to pay). }\end{array}$ & + & + & $=$ \\
\hline Austria & 2003 & $\begin{array}{l}\text { Employees Income Provision Act eliminated severance } \\
\text { paid and integrated into individual saving accounts ac- } \\
\text { cessible during unemployment spells }\end{array}$ & - & - & $=$ \\
\hline \multirow[t]{3}{*}{ Belgium } & 1997 & $\begin{array}{l}\text { Restriction on TWA were reduced and FTC were made } \\
\text { renewable }\end{array}$ & - & $=$ & - \\
\hline & 2000 & $\begin{array}{l}\text { Tightening of rule concerning notice period and compen- } \\
\text { sation in case of unjustified dismissal for blue collar work- } \\
\text { ers }\end{array}$ & $=$ & $=$ & $=$ \\
\hline & 2002 & $\begin{array}{l}\text { The maximum total duration of TWA was lengthened for } \\
\text { contracts justified by temporary increase in work-load } \\
\text { (Dec. 2001) }\end{array}$ & $=$ & $=$ & $=$ \\
\hline Canada & & No changes & & & \\
\hline \multirow{5}{*}{$\begin{array}{r}\text { Czech Republic } \\
\text { Denmark }\end{array}$} & & No changes & & & \\
\hline & 1995 & $\begin{array}{l}\text { Since the mid-1990s the role of TWA has been recognized } \\
\text { by social partners and their scope increased }\end{array}$ & - & $=$ & - \\
\hline & 1991 & $\begin{array}{l}\text { The delay before notice can start was shortened from } 2 \\
\text { months (as set in the Act on the Dismissal Procedure) to } \\
1-2 \text { weeks (as set in the Act of Employment Contracts) }\end{array}$ & - & - & $=$ \\
\hline & 1996 & $\begin{array}{l}\text { Notice period was halved for workers with tenure less than } \\
1 \text { year }\end{array}$ & - & - & $=$ \\
\hline & 2001 & $\begin{array}{l}\text { The new employment contract act came into force reduc- } \\
\text { ing notice periods further }\end{array}$ & - & - & $=$ \\
\hline \multirow[t]{3}{*}{ France } & 1986 & $\begin{array}{l}\text { Prior administrative authorization for dismissals for eco- } \\
\text { nomic reasons was abolished }\end{array}$ & - & - & $=$ \\
\hline & 1990 & $\begin{array}{l}\text { The list limiting the circumstances in which the use of } \\
\text { FTC and TWA is permissible is restored and the maxi- } \\
\text { mum total duration of FTC and TWA was reduced }\end{array}$ & + & $=$ & + \\
\hline & 2001 & Severance pay entitlements were increased & $=$ & + & $=$ \\
\hline \multirow[t]{6}{*}{ Germany } & 1985 & FTC were allowed without specifying an objective reason & & & \\
\hline & 1993 & $\begin{array}{l}\text { Notice period for blue collar workers was extended and } \\
\text { aligned with that of white collar workers }\end{array}$ & $=$ & + & $=$ \\
\hline & 1994 & TWA legislation was loosened & - & $=$ & - \\
\hline & 1996 & $\begin{array}{l}\text { The renewal period for FTC and TWA and admissible } \\
\text { frequency of renewals were increased }\end{array}$ & - & $=$ & - \\
\hline & 2002 & $\begin{array}{l}\text { Maximum total duration of TWA was brought to } 24 \\
\text { months }\end{array}$ & - & $=$ & - \\
\hline & 2004 & $\begin{array}{l}\text { The limit on the maximum total duration of TWA was } \\
\text { lifted. (from 1. Jan 2004) }\end{array}$ & - & $=$ & - \\
\hline \multirow[t]{3}{*}{ Greece } & 1990 & $\begin{array}{l}\text { Notice period or severance pay entitlements were reduced } \\
\text { (law 1989) amending law } 3198 / 55 \text { of } 1955 \text { ) }\end{array}$ & - & - & $=$ \\
\hline & 2003 & $\begin{array}{l}\text { National General Collective Labour Agreement (2002- } \\
\text { 2003) changes dismissal rules and raises slightly entitle- } \\
\text { ments to severance pay }\end{array}$ & - & - & $=$ \\
\hline & 2003 & PD $81 / 2003$ changes FTC and TWA & - & $=$ & - \\
\hline Hungary & 2003 & $\begin{array}{l}\text { The amended labour code introduced stricter regulations } \\
\text { on renewal of fixed term contracts }\end{array}$ & + & $=$ & + \\
\hline \multirow[t]{2}{*}{ Ireland } & 2003 & $\begin{array}{l}\text { The Protection of Employees act tightened regulation on } \\
\text { valid cases for FTC and limited their maximum overall } \\
\text { duration to } 4 \text { years }\end{array}$ & + & $=$ & + \\
\hline & 2003 & $\begin{array}{l}\text { The Redundancy Payments Bill (dismissal laws) raised } \\
\text { severance pay entitlements }\end{array}$ & $=$ & $=$ & $=$ \\
\hline \multirow[t]{4}{*}{ Italy } & 1987 & $\begin{array}{l}\text { Fixed term contracts use was widened through collec- } \\
\text { tive agreements specifying target groups and employment } \\
\text { shares }\end{array}$ & $=$ & $=$ & $=$ \\
\hline & 1997 & $\begin{array}{l}\text { Treu package on FTC widened the number of valid cases } \\
\text { for the use of FTC }\end{array}$ & - & $=$ & - \\
\hline & 1998 & TWA were permitted & - & $=$ & - \\
\hline & 2000 & $\begin{array}{l}\text { Reform of TWA } 2000 \text { extended the use of TWA and re- } \\
\text { moved the restrictions concerning unskilled workers }\end{array}$ & - & $=$ & - \\
\hline
\end{tabular}

Notes: Source: OECD (2004), pp.119-120. The equal sign indicates that the change in a sub-item was not large enough to be visible in the overall EPL index ; '-' ('+') indicates less (more) protection. Empty fields are also empty in the original source. 
Break points of Employment Protection Legislation (EPL) indices, continued.

\begin{tabular}{|c|c|c|c|c|c|}
\hline & & Reform description & EPL overall & EPL regular contracts & EPL temp. contracts \\
\hline \multirow[t]{3}{*}{ Japan } & 1985 & TWA were permitted for 13 occupations only & & & \\
\hline & 1996 & The use of TWA was extended to 26 occupations & - & $=$ & - \\
\hline & 1999 & $\begin{array}{l}\text { The use of TWA was extended to all occupations with } \\
\text { some exclusions }\end{array}$ & - & $=$ & - \\
\hline \multirow[t]{2}{*}{ Korea } & 1998 & TWA were liberalized & - & $=$ & - \\
\hline & 1998 & $\begin{array}{l}\text { Dismissals for managerial reasons are allowed (i.e. re- } \\
\text { dundancy and economic restructuring). Whereas this new } \\
\text { law may be used for dismissing a single person for urgent } \\
\text { business needs, it was mainly introduced with collective } \\
\text { dismissals in mind }\end{array}$ & - & - & $=$ \\
\hline \multirow{3}{*}{$\begin{array}{r}\text { Mexico } \\
\text { Netherlands }\end{array}$} & & No changes & & & \\
\hline & 1999 & $\begin{array}{l}\text { The flexibility and security law increased the maximum } \\
\text { possible number of FCT and lengthened the maximum } \\
\text { total duration of contracts with TWA }\end{array}$ & - & $=$ & - \\
\hline & 2001 & $\begin{array}{l}\text { The EU directive on fixed-term work came into effect re- } \\
\text { ducing the maximum total duration of TWA contracts }\end{array}$ & $=$ & $=$ & $=$ \\
\hline \multirow[t]{2}{*}{ New Zealand } & 2000 & $\begin{array}{l}\text { Employment relations act tightened the legislation on in- } \\
\text { dividual and collective dismissals }\end{array}$ & + & + & $=$ \\
\hline & 2000 & $\begin{array}{l}\text { Employment relations act also tightened the legislation } \\
\text { on FTC and TWA }\end{array}$ & + & $=$ & + \\
\hline \multirow[t]{2}{*}{ Norway } & 1995 & TWA legislation was eased & & $=$ & - \\
\hline & 2000 & TWA legislation was further eased & - & $=$ & - \\
\hline \multirow[t]{2}{*}{ Poland } & 2002 & $\begin{array}{l}\text { The new labour code lifted some restrictions in the use } \\
\text { of FTC (from } 2 \text { renewals permitted to unlimited - until } \\
\text { accession) }\end{array}$ & - & $=$ & - \\
\hline & 2003 & $\begin{array}{l}\text { A new law tightened regulations on temporary work agen- } \\
\text { cies limiting the cases when TWA contracts are allowed } \\
\text { and reducing their maximum total duration }\end{array}$ & + & $=$ & + \\
\hline \multirow[t]{2}{*}{ Poland } & 2002 & $\begin{array}{l}\text { The new labour code lifted some restrictions in the use } \\
\text { of FTC (from } 2 \text { renewals permitted to unlimited - until } \\
\text { accession) }\end{array}$ & - & $=$ & - \\
\hline & 2003 & $\begin{array}{l}\text { A new law tightened regulations on temporary work agen- } \\
\text { cies limiting the cases when TWA contracts are allowed } \\
\text { and reducing their maximum total duration }\end{array}$ & + & $=$ & + \\
\hline \multirow[t]{4}{*}{ Portugal } & 1989 & $\begin{array}{l}\text { Firing restrictions were eased (dismissals for individual } \\
\text { redundancy were authorised) }\end{array}$ & & & \\
\hline & 1991 & $\begin{array}{l}\text { Firing restrictions were eased further (dismissals for un- } \\
\text { suitability were authorised) }\end{array}$ & - & - & $=$ \\
\hline & 1996 & $\begin{array}{l}\text { A strategic social plan between social partners was agreed } \\
\text { to widen the use of FTC and TWA }\end{array}$ & - & $=$ & - \\
\hline & 2004 & New Labour Code came into force in December 2003 & - & $=$ & - \\
\hline \multirow[t]{2}{*}{ Slovak Republic } & 2003 & $\begin{array}{l}\text { A mew Labour code was approved that relaxed regula- } \\
\text { tions on dismissal of regular contract employees and col- } \\
\text { lective dismissals }\end{array}$ & - & - & $=$ \\
\hline & 2003 & $\begin{array}{l}\text { The new Labour code also increased valid cases for FTC, } \\
\text { raised the number of possible renewals and the maximum } \\
\text { overall duration of FTC }\end{array}$ & - & $=$ & - \\
\hline \multirow[t]{4}{*}{ Spain } & $\begin{array}{l}1984 \\
1994\end{array}$ & $\begin{array}{l}\text { Restrictions for FTC were substantially relaxed } \\
\text { Procedural requirements for dismissals for economic rea- } \\
\text { sons were relaxed, notice periods shortened }\end{array}$ & - & - & $=$ \\
\hline & 1994 & $\begin{array}{l}\text { Rules governing renewals of FTC were tightened and tem- } \\
\text { porary work agencies permitted }\end{array}$ & - & $=$ & - \\
\hline & 1997 & $\begin{array}{l}\text { Maximum compensation for unfair dismissal was reduced } \\
\text { and some changes were made to the definition of fair dis- } \\
\text { missal }\end{array}$ & - & - & $=$ \\
\hline & 2001 & $\begin{array}{l}\text { Law } 12 / 2001 \text { tightened the rules governing valid cases for } \\
\text { the use of FTC }\end{array}$ & + & $=$ & + \\
\hline Sweden & $\begin{array}{l}1993 \\
1997\end{array}$ & $\begin{array}{l}\text { TWA were permitted } \\
\text { FTC were made possible without objective reason }\end{array}$ & - & $\begin{array}{l}= \\
=\end{array}$ & - \\
\hline Switzerland & & No changes & & & \\
\hline \multirow{4}{*}{$\begin{array}{r}\text { Turkey } \\
\text { Great Britain }\end{array}$} & & No changes & & & \\
\hline & 1985 & $\begin{array}{l}\text { The period of service to claim unfair dismissal increased } \\
\text { to } 2 \text { years }\end{array}$ & & & \\
\hline & 2000 & Trial period was halved & + & + & $=$ \\
\hline & 2002 & $\begin{array}{l}\text { Maximum total duration of FTC was reduced to } 4 \text { years } \\
\text { (from unlimited) }\end{array}$ & $=$ & $=$ & + \\
\hline United States & & No changes & & & \\
\hline
\end{tabular}

Notes: Source: OECD (2004), pp.119-120. The equal sign indicates that the change in a sub-item was not large enough to be visible in the overall EPL index; '-' ("+') indicates less (more) protection. Empty fields are also empty in the original source. 
Table 8: Descriptive statistics and data sources

\begin{tabular}{|c|c|c|c|c|c|c|c|c|}
\hline \multirow{14}{*}{ نّ } & Variable & Obs. & Mean & Std. Dev. & Min & $\operatorname{Max}$ & Definition & Source \\
\hline & Employment protection regular & 401 & 2.19 & 0.96 & 0.17 & 5.00 & Index from $(0)$ to $(5)$ & OECD (2004) \\
\hline & Employment protection temporary & 401 & 2.19 & 1.59 & 0.25 & 5.38 & Index from $(0)$ to $(5)$ & OECD $(2004)$ \\
\hline & Globalization, overall index & 401 & 73.01 & 12.04 & 41.46 & 93.21 & Indicator from $(0)$ to $(100)$ & Dreher (2006) \\
\hline & Economic globalization & 401 & 73.49 & 12.47 & 37.75 & 96.04 & Indicator from $(0)$ to $(100)$ & Dreher (2006) \\
\hline & Political globalization & 401 & 79.93 & 12.95 & 39.41 & 99.00 & Indicator from $(0)$ to $(100)$ & Dreher (2006) \\
\hline & Social globalization & 401 & 67.86 & 16.93 & 19.83 & 92.04 & Indicator from $(0)$ to $(100)$ & Dreher (2006) \\
\hline & $\log G D P$ & 401 & 9.88 & 0.35 & 8.54 & 10.46 & $\begin{array}{l}\text { National income } \\
\text { (I) }(100)\end{array}$ & World Bank (2009) \\
\hline & Unemployment rate & 401 & 8.43 & 4.08 & 1.60 & 23.90 & Share of unemployed in active population & OECD (2009) \\
\hline & Log unemployment spending & 401 & 0.11 & 0.80 & -2.30 & 1.67 & Unemployment spending as share of GDP & OECD $(2009)$ \\
\hline & Union density & 342 & 38.48 & 21.01 & 8.20 & 83.86 & Percentage of union members in dependent workforce & Dreher and Gaston (2005) \\
\hline & 5-year GDP growth & 401 & 0.11 & 0.09 & -0.16 & 0.51 & $(\operatorname{GDP}-\operatorname{GDP}(-5)) / \operatorname{GDP}(-5)$ & \\
\hline & Left-wing government & 401 & 0.45 & 0.50 & 0.00 & 1.00 & Dummy variable. & Beck et al. (2001) \\
\hline & Right-wing government & 401 & 0.26 & 0.36 & -0.57 & 1.00 & Continuous measure & Bjørnskov (2008) \\
\hline
\end{tabular}

Notes: based on regression sample of Tables 1, 2 and 13 (union density). 
Table 9: Globalization and protection of regularly employed, 1985-2003, parsimonious model

\begin{tabular}{|c|c|c|c|c|c|}
\hline & (1) & (2) & (3) & (4) & (5) \\
\hline $\log G D P(-2)$ & $\begin{array}{c}-0.351^{* * *} * \\
{[2.94]}\end{array}$ & $\begin{array}{c}-0.369^{* * *} \\
{[3.11]}\end{array}$ & $\begin{array}{c}-0.400^{* * *} \\
{[3.36]}\end{array}$ & $\begin{array}{c}-0.348^{* * *} \\
{[2.85]}\end{array}$ & $\begin{array}{c}-0.369^{* * *} \\
{[3.03]}\end{array}$ \\
\hline Log Population (-2) & $\begin{array}{c}1.186^{* * * *} \\
{[3.35]}\end{array}$ & $\begin{array}{c}1.152^{* * * *} \\
{[3.26]}\end{array}$ & $\begin{array}{c}1.282^{* * *} * \\
{[3.68]}\end{array}$ & $\begin{array}{c}1.610 * * * \\
{[4.60]}\end{array}$ & $\begin{array}{c}1.455^{* * * *} \\
{[4.04]}\end{array}$ \\
\hline Globalization, overall (-2) & $\begin{array}{c}-0.015 * * * \\
{[5.09]}\end{array}$ & & & & \\
\hline Economic glob. (-2) & & $\begin{array}{c}-0.011 * * * \\
{[5.07]}\end{array}$ & $\begin{array}{c}-0.012^{* * * *} \\
{[5.24]}\end{array}$ & & \\
\hline Political glob. (-2) & & $\begin{array}{c}-0.004^{* *} \\
{[2.38]}\end{array}$ & & $\begin{array}{c}-0.004^{* *} \\
{[2.43]}\end{array}$ & \\
\hline Social glob. (-2) & & $\begin{array}{c}-0.002 \\
{[1.37]}\end{array}$ & & & $\begin{array}{c}-0.004^{* *} \\
{[2.27]}\end{array}$ \\
\hline Constant & $\begin{array}{c}-7.616^{*} \\
{[1.65]}\end{array}$ & $\begin{array}{l}-6,789 \\
{[1.47]}\end{array}$ & $\begin{array}{c}-8.508^{*} \\
{[1.87]}\end{array}$ & $\begin{array}{c}-13.684^{* * *} \\
{[3.02]}\end{array}$ & $\begin{array}{c}-11.613^{* *} \\
{[2.49]}\end{array}$ \\
\hline Observations & 480 & 480 & 480 & 480 & 480 \\
\hline Number of countries & 28 & 28 & 28 & 28 & 28 \\
\hline R-squared (within) & 0.18 & 0.20 & 0.18 & 0.14 & 0.14 \\
\hline
\end{tabular}

Notes: Dependent variable is the Employment Protection Index for regularly employed workers (OECD, 2004), ranging from 0 to 6. OLS estimation with country and year fixed effects (not reported). Globalization is measured on a scale ranging from 0 to 100 (Dreher, 2006). Absolute value of t-statistics in brackets. '*', ‘**, '***' denote statistical significance at $10 \%, 5 \%$ and $1 \%$ levels respectively.

Table 10: Globalization and protection of atypically employed, 1985-2003, parsimonious model

\begin{tabular}{|c|c|c|c|c|c|}
\hline & (1) & (2) & (3) & (4) & (5) \\
\hline $\log G D P(-2)$ & $\begin{array}{c}0.935^{* * *} \\
{[3.12]}\end{array}$ & $\begin{array}{c}0.888^{* * *} \\
{[2.97]}\end{array}$ & $\begin{array}{c}0.974^{* * *} \\
{[3.21]}\end{array}$ & $\begin{array}{c}0.910^{* * *} \\
{[3.01]}\end{array}$ & $\begin{array}{c}0.951^{* * *} \\
{[3.18]}\end{array}$ \\
\hline Log Population (-2) & $\begin{array}{c}7.221 * * * \\
{[8.11]}\end{array}$ & $\begin{array}{c}7.110^{* * * *} \\
{[7.97]}\end{array}$ & $\begin{array}{c}6.399 * * * \\
{[7.19]}\end{array}$ & $\begin{array}{c}6.530 * * * \\
{[7.53]}\end{array}$ & $\begin{array}{c}7.205^{* * * *} \\
{[8.16]}\end{array}$ \\
\hline Globalization, overall (-2) & $\begin{array}{c}0.025^{* * *} * \\
{[3.41]}\end{array}$ & & & & \\
\hline Economic glob. (-2) & & $\begin{array}{c}-0.004 \\
{[0.77]}\end{array}$ & $\begin{array}{c}-0.002 \\
{[0.31]}\end{array}$ & & \\
\hline Political glob. (-2) & & $\begin{array}{c}0.008^{* *} \\
{[2.01]}\end{array}$ & & $\begin{array}{c}0.010^{* *} \\
{[2.41]}\end{array}$ & \\
\hline Social glob. (-2) & & $\begin{array}{c}0.016^{* * * *} \\
{[3.56]}\end{array}$ & & & $\begin{array}{c}0.016^{* * *} \\
{[3.73]}\end{array}$ \\
\hline Constant & $\begin{array}{c}-97.718^{* * *} \\
{[8.43]}\end{array}$ & $\begin{array}{c}-95.419^{* * * *} \\
{[8.19]}\end{array}$ & $\begin{array}{c}-85.818^{* * *} \\
{[7.39]}\end{array}$ & $\begin{array}{c}-87.842^{* * *} \\
{[7.83]}\end{array}$ & $\begin{array}{c}-96.917^{* * *} \\
{[8.47]}\end{array}$ \\
\hline Observations & 480 & 480 & 480 & 480 & 480 \\
\hline Number of countries & 28 & 28 & 28 & 28 & 28 \\
\hline R-squared (within) & 0.34 & 0.35 & 0.33 & 0.33 & 0.35 \\
\hline
\end{tabular}

Notes: Dependent variable is the Employment Protection Index for atypically employed workers (OECD, 2004), ranging from 0 to 6 . OLS estimation with country and year fixed effects (not reported). Globalization is measured on a scale ranging from 0 to 100 (Dreher, 2006). Absolute value of t-statistics in brackets. '*', '**', '***, denote statistical significance at $10 \%, 5 \%$ and $1 \%$ levels respectively. 
Table 11: Globalization and protection of regularly employed, 1985-2003, OECD countries with no communist past

\begin{tabular}{|c|c|c|c|c|c|}
\hline & (1) & (2) & (3) & (4) & $(5)$ \\
\hline $\log G D P(-2)$ & $\begin{array}{l}-0.512 \\
{[1.51]}\end{array}$ & $\begin{array}{c}-0.498 \\
{[1.51]}\end{array}$ & $\begin{array}{c}-0.802^{* *} \\
{[2.53]}\end{array}$ & $\begin{array}{c}-0.865^{* * *} \\
{[2.71]}\end{array}$ & $\begin{array}{c}-1.070^{* * *} \\
{[3.21]}\end{array}$ \\
\hline Log Population (-2) & $\begin{array}{c}2.360^{* * * *} \\
{[5.84]}\end{array}$ & $\begin{array}{c}2.623 * * * \\
{[6.52]}\end{array}$ & $\begin{array}{c}2.540^{* * * *} \\
{[6.38]}\end{array}$ & $\begin{array}{c}2.793^{* * *} * \\
{[6.98]}\end{array}$ & $\begin{array}{c}2.668^{* * *} * \\
{[6.33]}\end{array}$ \\
\hline Unemployment rate (-2) & $\begin{array}{l}0.005 \\
{[0.82]}\end{array}$ & $\begin{array}{l}0.007 \\
{[1.18]}\end{array}$ & $\begin{array}{l}0.008 \\
{[1.34]}\end{array}$ & $\begin{array}{l}0.000 \\
{[0.04]}\end{array}$ & $\begin{array}{l}0.002 \\
{[0.31]}\end{array}$ \\
\hline Log unemployment spending (-2) & $\begin{array}{c}-0.074^{* *} \\
{[2.16]}\end{array}$ & $\begin{array}{c}-0.073^{* *} \\
{[2.11]}\end{array}$ & $\begin{array}{c}-0.101 * * * \\
{[2.92]}\end{array}$ & $\begin{array}{l}-0.056 \\
{[1.57]}\end{array}$ & $\begin{array}{c}-0.082^{* *} \\
{[2.32]}\end{array}$ \\
\hline GDP growth (-2) & $\begin{array}{l}0.022 \\
{[1.23]}\end{array}$ & $\begin{array}{l}0.025 \\
{[1.45]}\end{array}$ & $\begin{array}{c}0.038^{* *} \\
{[2.22]}\end{array}$ & $\begin{array}{c}0.041^{* *} \\
{[2.38]}\end{array}$ & $\begin{array}{c}0.048 * * * \\
{[2.68]}\end{array}$ \\
\hline Left-wing govt. (-2) & $\begin{array}{c}0.053 * * * \\
{[2.62]}\end{array}$ & $\begin{array}{c}0.058^{* * * *} \\
{[2.88]}\end{array}$ & $\begin{array}{c}0.043^{* * *} \\
{[2.15]}\end{array}$ & $\begin{array}{c}0.057^{* * *} * \\
{[2.74]}\end{array}$ & $\begin{array}{c}0.045^{* *} \\
{[2.14]}\end{array}$ \\
\hline Globalization, overall (-2) & $\begin{array}{c}-0.017 * * * \\
{[4.39]}\end{array}$ & & & & \\
\hline Economic glob. (-2) & & $\begin{array}{c}-0.013 * * * \\
{[4.93]}\end{array}$ & $\begin{array}{c}-0.012 * * * \\
{[4.40]}\end{array}$ & & \\
\hline Political glob. (-2) & & $\begin{array}{c}-0.008^{* * *} \\
{[4.25]}\end{array}$ & & $\begin{array}{c}-0.007 * * * \\
{[3.64]}\end{array}$ & \\
\hline Social glob. (-2) & & $\begin{array}{l}0.000 \\
{[0.11]}\end{array}$ & & & $\begin{array}{c}-0.001 \\
{[0.43]}\end{array}$ \\
\hline Constant & $\begin{array}{c}-20.768^{* * * *} \\
{[3.73]}\end{array}$ & $\begin{array}{c}-23.794^{* * *} \\
{[4.32]}\end{array}$ & $\begin{array}{c}-20.705^{* * *} \\
{[3.72]}\end{array}$ & $\begin{array}{c}-23.366^{* * *} \\
{[4.13]}\end{array}$ & $\begin{array}{c}-20.477^{* * *} \\
{[3.56]}\end{array}$ \\
\hline Observations & 370 & 370 & 370 & 370 & 370 \\
\hline Number of countries & 22 & 22 & 22 & 22 & 22 \\
\hline$R$-squared (within) & 0.32 & 0.36 & 0.32 & 0.31 & 0.28 \\
\hline
\end{tabular}

Notes: Dependent variable is the Employment Protection Index for regularly employed workers (OECD, 2004), ranging from 0 to 6. OLS estimation with country and year fixed effects (not reported). Globalization is measured on a scale ranging from 0 to 100 (Dreher, 2006). Absolute value of t-statistics in brackets. '*', ‘**', ‘***' denote statistical significance at 10\%, 5\% and $1 \%$ levels respectively. 
Table 12: Globalization and protection of atypically employed, 1985-2003, OECD countries with no communist past

\begin{tabular}{|c|c|c|c|c|c|}
\hline & (1) & (2) & (3) & (4) & $(5)$ \\
\hline $\log G D P(-2)$ & $\begin{array}{c}2.252^{* *} \\
{[2.45]}\end{array}$ & $\begin{array}{c}2.306^{* *} \\
{[2.57]}\end{array}$ & $\begin{array}{c}3.752^{* * *} \\
{[4.32]}\end{array}$ & $\begin{array}{c}2.990^{* * *} \\
{[3.46]}\end{array}$ & $\begin{array}{c}2.248^{* *} \\
{[2.59]}\end{array}$ \\
\hline Log Population (-2) & $\begin{array}{l}9.343 * * * \\
{[8.51]}\end{array}$ & $\begin{array}{l}9.579 * * * \\
{[8.74]}\end{array}$ & $\begin{array}{l}8.469 * * * \\
{[7.76]}\end{array}$ & $\begin{array}{l}8.536^{* * * *} \\
{[7.87]}\end{array}$ & $9.893^{* * * *}$ \\
\hline Unemployment rate (-2) & $\begin{array}{l}0.000 \\
{[0.00]}\end{array}$ & $\begin{array}{l}0.012 \\
{[0.74]}\end{array}$ & $\begin{array}{l}0.014 \\
{[0.79]}\end{array}$ & $\begin{array}{l}0.009 \\
{[0.52]}\end{array}$ & $\begin{array}{l}0.003 \\
0.18\end{array}$ \\
\hline Log unemployment spending (-2) & $\begin{array}{l}-0.114 \\
{[1.22]}\end{array}$ & $\begin{array}{c}-0.159^{*} \\
{[1.69]}\end{array}$ & $\begin{array}{c}-0.120 \\
{[1.27]}\end{array}$ & $\begin{array}{c}-0.143 \\
{[1.49]}\end{array}$ & $\begin{array}{c}-0.105 \\
{[1.13]}\end{array}$ \\
\hline GDP growth (-2) & $\begin{array}{c}-0.040 \\
{[0.82]}\end{array}$ & $\begin{array}{c}-0.036 \\
{[0.75]}\end{array}$ & $\begin{array}{c}-0.110^{* *} \\
{[2.36]}\end{array}$ & $\begin{array}{c}-0.078^{*} \\
{[1.69]}\end{array}$ & $\begin{array}{c}-0.033 \\
{[0.69]}\end{array}$ \\
\hline Left-wing govt. (-2) & $\begin{array}{l}0.058 \\
{[1.05]}\end{array}$ & $\begin{array}{l}0.052 \\
{[0.95]}\end{array}$ & $\begin{array}{l}0.075 \\
{[1.34]}\end{array}$ & $\begin{array}{l}0.055 \\
{[0.97]}\end{array}$ & $\begin{array}{l}0.068 \\
{[1.26]}\end{array}$ \\
\hline Globalization, overall (-2) & $\begin{array}{c}0.032 * * * \\
{[3.08]}\end{array}$ & & & & \\
\hline Economic glob. (-2) & & $\begin{array}{c}-0.013^{*} \\
{[1.83]}\end{array}$ & $\begin{array}{c}-0.013^{*} \\
{[1.81]}\end{array}$ & & \\
\hline Political glob. (-2) & & $\begin{array}{c}0.009^{*} \\
{[1.71]}\end{array}$ & & $\begin{array}{c}0.012^{* *} \\
{[2.22]}\end{array}$ & \\
\hline Social glob. (-2) & & $\begin{array}{c}0.024 * * * \\
{[4.26]}\end{array}$ & & & $\begin{array}{c}0.025 * * * \\
{[4.33]}\end{array}$ \\
\hline Constant & $\begin{array}{c}-133.681^{* * *} \\
{[8.84]}\end{array}$ & $\begin{array}{c}-136.404^{* * *} \\
{[9.09]}\end{array}$ & $\begin{array}{c}-133.798^{* * *} \\
{[8.77]}\end{array}$ & $\begin{array}{c}-129.395^{* * *} \\
{[8.43]}\end{array}$ & $\begin{array}{c}-139.832^{* * *} \\
{[9.34]}\end{array}$ \\
\hline Observations & 370 & 370 & 370 & 370 & 370 \\
\hline Number of countries & 22 & 22 & 22 & 22 & 22 \\
\hline$R$-squared (within) & 0.44 & 0.47 & 0.43 & 0.43 & 0.46 \\
\hline
\end{tabular}

Notes: Dependent variable is the Employment Protection Index for atypically employed workers (OECD, 2004), ranging from 0 to 6 . OLS estimation with country and year fixed effects (not reported). Globalization is measured on a scale ranging from 0 to 100 (Dreher, 2006). Absolute value of t-statistics in brackets. '*', ‘**', '***' denote statistical significance at $10 \%, 5 \%$ and $1 \%$ levels respectively. 
Table 13: Globalization and protection of regularly employed, 1985-2003, controlling for union density

\begin{tabular}{|c|c|c|c|c|c|}
\hline & (1) & (2) & (3) & (4) & (5) \\
\hline $\log G D P(-2)$ & $-0.990^{* * *}$ & $-0.966^{* *}$ & $-1.255^{* * *}$ & $-1.474^{* * *}$ & $-1.517^{* * *}$ \\
\hline & {$[2.66]$} & {$[2.59]$} & {$[3.24]$} & [4.01] & {$[4.00]$} \\
\hline Log Population (-2) & $\begin{array}{c}1.661 * * * \\
{[3.64]}\end{array}$ & $\begin{array}{l}1.971^{* * * *} \\
{[4.17]}\end{array}$ & $\begin{array}{l}2.330 * * * \\
{[5.11]}\end{array}$ & $\begin{array}{c}2.547 * * * \\
{[5.69]}\end{array}$ & $\begin{array}{c}1.940^{* * * *} \\
{[3.88]}\end{array}$ \\
\hline Unemployment rate (-2) & $\begin{array}{l}0.008 \\
{[1.29]}\end{array}$ & $\begin{array}{l}0.006 \\
{[0.93]}\end{array}$ & $\begin{array}{l}0.008 \\
{[1.19]}\end{array}$ & $\begin{array}{c}-0.002 \\
{[0.32]}\end{array}$ & $\begin{array}{l}0.004 \\
{[0.55]}\end{array}$ \\
\hline Log unemployment spending (-2) & $\begin{array}{c}-0.037 \\
{[1.13]}\end{array}$ & $\begin{array}{c}-0.021 \\
{[0.61]}\end{array}$ & $\begin{array}{c}-0.079^{* *} \\
{[2.26]}\end{array}$ & $\begin{array}{c}-0.008 \\
{[0.23]}\end{array}$ & $\begin{array}{c}-0.054 \\
{[1.55]}\end{array}$ \\
\hline Union density (-2) & $\begin{array}{c}-0.016^{* * *} \\
{[6.34]}\end{array}$ & $\begin{array}{c}-0.015^{* * *} * \\
{[5.46]}\end{array}$ & $\begin{array}{c}-0.011 * * * \\
{[4.19]}\end{array}$ & $\begin{array}{c}-0.015^{* * *} \\
{[5.66]}\end{array}$ & $\begin{array}{c}-0.016^{* * *} * \\
{[5.62]}\end{array}$ \\
\hline GDP growth (-2) & $\begin{array}{c}0.047^{* *} * \\
{[2.35]}\end{array}$ & $\begin{array}{c}0.046^{* *} \\
{[2.29]}\end{array}$ & $\begin{array}{c}0.053^{* *} * \\
{[2.55]}\end{array}$ & $\begin{array}{c}0.067 * * * \\
{[3.35]}\end{array}$ & $\begin{array}{c}0.067 * * * \\
{[3.29]}\end{array}$ \\
\hline Right-wing govt., continuous (-2) & $\begin{array}{c}-0.129 * * * \\
{[4.08]}\end{array}$ & $\begin{array}{c}-0.132^{* * *} \\
{[4.19]}\end{array}$ & $\begin{array}{c}-0.094^{* * *} * \\
{[2.92]}\end{array}$ & $\begin{array}{c}-0.113^{* * *} * \\
{[3.52]}\end{array}$ & $\begin{array}{c}-0.101^{* * *} * \\
{[3.08]}\end{array}$ \\
\hline Globalization, overall (-2) & $\begin{array}{c}-0.025 * * * \\
{[6.27]}\end{array}$ & & & & \\
\hline Economic glob. (-2) & & $\begin{array}{c}-0.010^{* * *} \\
{[3.33]}\end{array}$ & $\begin{array}{c}-0.011^{* * *} \\
{[3.73]}\end{array}$ & & \\
\hline Political glob. (-2) & & $\begin{array}{c}-0.011^{* * *} * \\
{[5.23]}\end{array}$ & & $\begin{array}{c}-0.010 * * * \\
{[4.89]}\end{array}$ & \\
\hline Social glob. (-2) & & $\begin{array}{c}-0.006^{* *} \\
{[2.32]}\end{array}$ & & & $\begin{array}{c}-0.007 * * * \\
{[2.72]}\end{array}$ \\
\hline Constant & $\begin{array}{c}-6,736 \\
{[0.98]}\end{array}$ & $\begin{array}{c}-10,592 \\
{[1.49]}\end{array}$ & $\begin{array}{c}-13.459^{*} \\
{[1.89]}\end{array}$ & $\begin{array}{c}-13.917^{* *} \\
{[1.99]}\end{array}$ & $\begin{array}{c}-6,540 \\
{[0.88]}\end{array}$ \\
\hline Observations & 342 & 342 & 342 & 342 & 342 \\
\hline Number of countries & 20 & 20 & 20 & 20 & 20 \\
\hline R-squared (within) & 0.42 & 0.43 & 0.37 & 0.39 & 0.36 \\
\hline
\end{tabular}

Notes: Dependent variable is the Employment Protection Index for regularly employed workers (OECD, 2004), ranging from 0 to 6. OLS estimation with country and year fixed effects (not reported). Globalization is measured on a scale ranging from 0 to 100 (Dreher, 2006). Absolute value of t-statistics in brackets. '*', '**', '***' denote statistical significance at $10 \%, 5 \%$ and $1 \%$ levels respectively. 
Table 14: Globalization and protection of atypically employed, 1985-2003, controlling for union density

\begin{tabular}{|c|c|c|c|c|c|}
\hline & (1) & (2) & (3) & (4) & (5) \\
\hline \multirow[t]{2}{*}{$\log G D P(-2)$} & $2.401^{* *}$ & $3.012^{* * *}$ & $3.709 * * *$ & $3.060^{* * *}$ & $2.725^{* * *}$ \\
\hline & {$[2.29]$} & [2.93] & {$[3.50]$} & {$[3.02]$} & {$[2.72]$} \\
\hline \multirow[t]{2}{*}{ Log Population (-2) } & $10.171^{* * *}$ & $11.140 * * *$ & $8.927 * * *$ & $8.971^{* * *}$ & $11.115^{* * *}$ \\
\hline & {$[7.94]$} & {$[8.56]$} & {$[7.16]$} & {$[7.27]$} & {$[8.40]$} \\
\hline \multirow[t]{2}{*}{ Unemployment rate (-2) } & -0.008 & 0.005 & 0.007 & 0.005 & -0.009 \\
\hline & {$[0.48]$} & [0.31] & [0.39] & {$[0.29]$} & {$[0.50]$} \\
\hline \multirow[t]{2}{*}{ Log unemployment spending (-2) } & -0.098 & $-0.195^{* *}$ & -0.089 & -0.136 & -0.085 \\
\hline & {$[1.05]$} & {$[2.04]$} & {$[0.93]$} & {$[1.40]$} & {$[0.92]$} \\
\hline \multirow{2}{*}{ Union density (-2) } & -0.006 & 0.008 & -0.008 & -0.008 & 0.000 \\
\hline & {$[0.79]$} & {$[1.00]$} & {$[1.10]$} & {$[1.09]$} & {$[0.05]$} \\
\hline \multirow[t]{2}{*}{ GDP growth (-2) } & -0.076 & $-0.112^{* *}$ & $-0.128^{* *}$ & $-0.103^{*}$ & $-0.092^{*}$ \\
\hline & {$[1.37]$} & {$[2.05]$} & {$[2.25]$} & [1.88] & [1.71] \\
\hline \multirow[t]{2}{*}{ Right-wing govt., continuous (-2) } & 0.122 & $0.156^{*}$ & 0.059 & 0.100 & 0.120 \\
\hline & {$[1.38]$} & {$[1.80]$} & {$[0.67]$} & {$[1.13]$} & {$[1.38]$} \\
\hline Globalization, overall (-2) & $\begin{array}{c}0.034^{* * * *} \\
{[3.03]}\end{array}$ & & & & \\
\hline Economic glob. (-2) & & $\begin{array}{c}-0.019^{* *} \\
{[2.28]}\end{array}$ & $\begin{array}{c}-0.010 \\
{[1.23]}\end{array}$ & & \\
\hline Political glob. (-2) & & $\begin{array}{c}0.015^{* * *} * \\
{[2.70]}\end{array}$ & & $\begin{array}{c}0.014^{* *} \\
{[2.38]}\end{array}$ & \\
\hline Social glob. (-2) & & $\begin{array}{c}0.032 * * * \\
{[4.56]}\end{array}$ & & & $\begin{array}{c}0.027^{* * *} * \\
{[3.91]}\end{array}$ \\
\hline Constant & $\begin{array}{c}-144.429 * * * \\
{[7.47]} \\
\end{array}$ & $\begin{array}{c}-161.662^{* * *} \\
{[8.27]}\end{array}$ & $\begin{array}{c}-138.408^{* * * *} \\
{[7.11]}\end{array}$ & $\begin{array}{c}-134.717^{* * *} \\
{[6.97]} \\
\end{array}$ & $\begin{array}{c}-158.295^{* * *} \\
{[8.01]}\end{array}$ \\
\hline Observations & 342 & 342 & 342 & 342 & 342 \\
\hline Number of countries & 20 & 20 & 20 & 20 & 20 \\
\hline R-squared (within) & 0.46 & 0.49 & 0.45 & 0.46 & 0.47 \\
\hline
\end{tabular}

Notes: Dependent variable is the Employment Protection Index for atypically employed workers (OECD, 2004), ranging from 0 to 6. OLS estimation with country and year fixed effects (not reported). Globalization is measured on a scale ranging from 0 to 100 (Dreher, 2006). Absolute value of t-statistics in brackets. '*', '**, '***, denote statistical significance at $10 \%, 5 \%$ and $1 \%$ levels respectively. 